The First Acheulian Quarry in India: Stone Tool Manufacture, Biface Morphology, and Behaviors

Author(s): Michael Petraglia, Philip LaPorta and K. Paddayya

Source: Journal of Anthropological Research, Vol. 55, No. 1 (Spring, 1999), pp. 39-70

Published by: The University of Chicago Press

Stable URL: http://www.jstor.org/stable/3630977

Accessed: 22-07-2016 09:54 UTC

Your use of the JSTOR archive indicates your acceptance of the Terms \& Conditions of Use, available at

http://about.jstor.org/terms

JSTOR is a not-for-profit service that helps scholars, researchers, and students discover, use, and build upon a wide range of content in a trusted digital archive. We use information technology and tools to increase productivity and facilitate new forms of scholarship. For more information about JSTOR, please contact support@jstor.org.

The University of Chicago Press is collaborating with JSTOR to digitize, preserve and extend access to Journal of Anthropological Research 


\title{
THE FIRST ACHEULIAN QUARRY IN INDIA: STONE TOOL MANUFACTURE, BIFACE MORPHOLOGY, AND BEHAVIORS ${ }^{1}$
}

\author{
Michael Petraglia \\ Department of Anthropology, National Museum of Natural History, \\ Smithsonian Institution, Washington, DC 20560, USA \\ Philip LaPorta \\ Department of Earth and Environmental Sciences, City University of New York, \\ New York, NY 10036, USA \\ K. Paddayya \\ Department of Archaeology, Deccan College, 411 006, Pune, India
}

\begin{abstract}
An Acheulian quarry was recently identified in the Hunsgi Valley, India. An Acheulian quarry has never been described before on the Indian subcontinent, and this is a site type that has rarely been investigated anywhere in the Old World. The Isampur quarry is at a siliceous limestone bedrock source. Surface survey and test excavations have revealed Acheulian assemblages, including a high density of chipped stone waste (i.e., cores, flakes, chunks), bifacial tools (i.e., bifaces, cleavers), and hammerstones. Petrofabric analysis of the limestone beds and study of artifact attributes indicate that hominids practiced standardized biface manufacturing methods at this quarry. Handaxes were made parallel to moderately thick tabular slabs, the handaxe tips and butts often intersecting with joints. Cleavers were made on side-struck flakes from thick cores, which were derived from the thickest limestone beds. The dorsal surface of the side-struck cleavers was often subparallel to a bedding plane, and the bit was inclined into a cleavage scar or joint. The steps involved in biface manufacture prior to and during the reduction process indicate that a significant degree of planning was employed, an important observation given our lack of understanding of Middle Pleistocene hominid cognition. Repeated manufacture of certain tool types and discard of minimally retouched bifaces across the valley floors indicate relations between raw materials and behaviors that we do not yet fully comprehend.
\end{abstract}

ARCHAEOLOGISTS EXPLICITLY OR IMPLICITLY employ taxonomic designations to examine Paleolithic issues, as exemplified in temporally and spatially defined divisions (e.g., Lower, Middle, Upper Paleolithic) and subdivisions (e.g., Oldowan, Acheulian, Mousterian, Magdalenian). However, archaeologists continue to debate the meaning of stone tool classifications defined by morphological criteria. Some lithic analysts consider stone tool types to be the result of sociocultural norms, while others view them as the products of functional variability and/or the physical constraints imposed by raw material. Related disagreements about the meaning of Paleolithic interassemblage variability are illustrated by ongoing debates on the Middle Paleolithic (e.g., Dibble 1987, 1995; Barton 1990; Rolland and Dibble 1990; Mellars 1996) and the Epi-Paleolithic (e.g., Neeley and Barton 1994; Kaufman 1995; Goring-Morris 1996).

Journal of Anthropological Research, vol. 55, 1999

Copyright (C) by The University of New Mexico 
While archaeologists have been relatively comfortable with the notion that an "Acheulian" industry can be identified based on characteristic tool styles (e.g., Bordes 1961; Leakey 1971) and manufacturing techniques (e.g., Bar-Yosef 1994; Belfer-Cohen and Goren-Inbar 1994; Clark 1994; Schick 1994), arguments are beginning to emerge that indicate an increasing level of dissatisfaction with the term "Acheulian" as a descriptive name or culture-stratigraphic unit, in which types are considered to represent shared norms in tool making. Certain researchers contend that modal Acheulian tool classifications constitute a continuum in tool flaking and use by hominids. In addition, converging morphological similarities in tool types may be seen as the result of physical attributes such as raw material types, initial forms, and availability and of behavioral factors evidenced by tool reshaping and retouch intensity (e.g., Davidson and Noble 1993; McPherron 1994; Dibble 1995; Barton 1997; Noll and Ambrose 1998). Thus, the question remains whether Acheulian biface morphologies are the product of intentionally imposed designs (i.e., "mental templates"), the physical properties of raw materials, and/or a suite of functional factors (e.g., use, intensity of site occupation, degree of mobility).

This article describes the recent work carried out at Isampur, an Acheulian limestone quarry in India. The Isampur quarry is the first archaeological occurrence of its kind to be reported on the Indian subcontinent (Paddayya and Petraglia 1997a, 1997b), complementing the recent discovery of the oldest known Acheulian quarry in Africa (Potts and Noll 1998). The recovery of bifaces at the Isampur quarry can be used to examine stone tool manufacturing techniques at the geological outcrop (Ericson and Purdy 1984), thereby contributing to a better understanding of the stages of biface manufacture (e.g., Callahan 1979; Schick 1994). As a quarry locus, transport and reshaping of bifaces through use at Isampur is nil to slight, thus allowing an opportunity to study the relative influence of raw materials (e.g., Jones 1979; Kuhn 1992; Leng 1992; Andrefsky 1994; White 1995) and the imposition of form (e.g., Wynn 1979, 1989; Gowlett 1984; Isaac 1986). This study represents a departure from common stone tool analyses by adding a study of rock fabric in biface manufacture (see LaPorta 1997, 1999).

The first section of this article provides a general background of the research conducted in the Hunsgi and Baichbal Valleys. This is followed by a preliminary overview of the Isampur locality, the nature of the archaeological investigations, and a description of the recovered artifact assemblages. The final section provides a discussion about the meaning of stone tool assemblages. The aim of this article is to review the salient aspects of recent findings and their potential implications; excavations at the quarry are ongoing, and detailed quantitative descriptions of the assemblages will be provided in forthcoming publications.

\section{THE HUNSGI AND BAICHBAL VALLEYS}

The Hunsgi and Baichbal Valleys are located in the Gulbarga District of Karnataka, south-central India, in the physiographic province known as the 
Deccan Plateau. The valleys are separated from each other by a narrow remnant of a shale-limestone plateau (Figure 1). The area constitutes a single basin of Tertiary age, measuring $500 \mathrm{~km}^{2}$ in extent. The basin is flanked on its western and southern sides by shale-limestone plateaus and capped by the volcanic basalts of the Deccan Trap. Shallow, but perennial, water bodies occur in the area due to the activity of seep springs emanating from the junction of shales and limestones. The occurrence of thick and extensive travertine de-

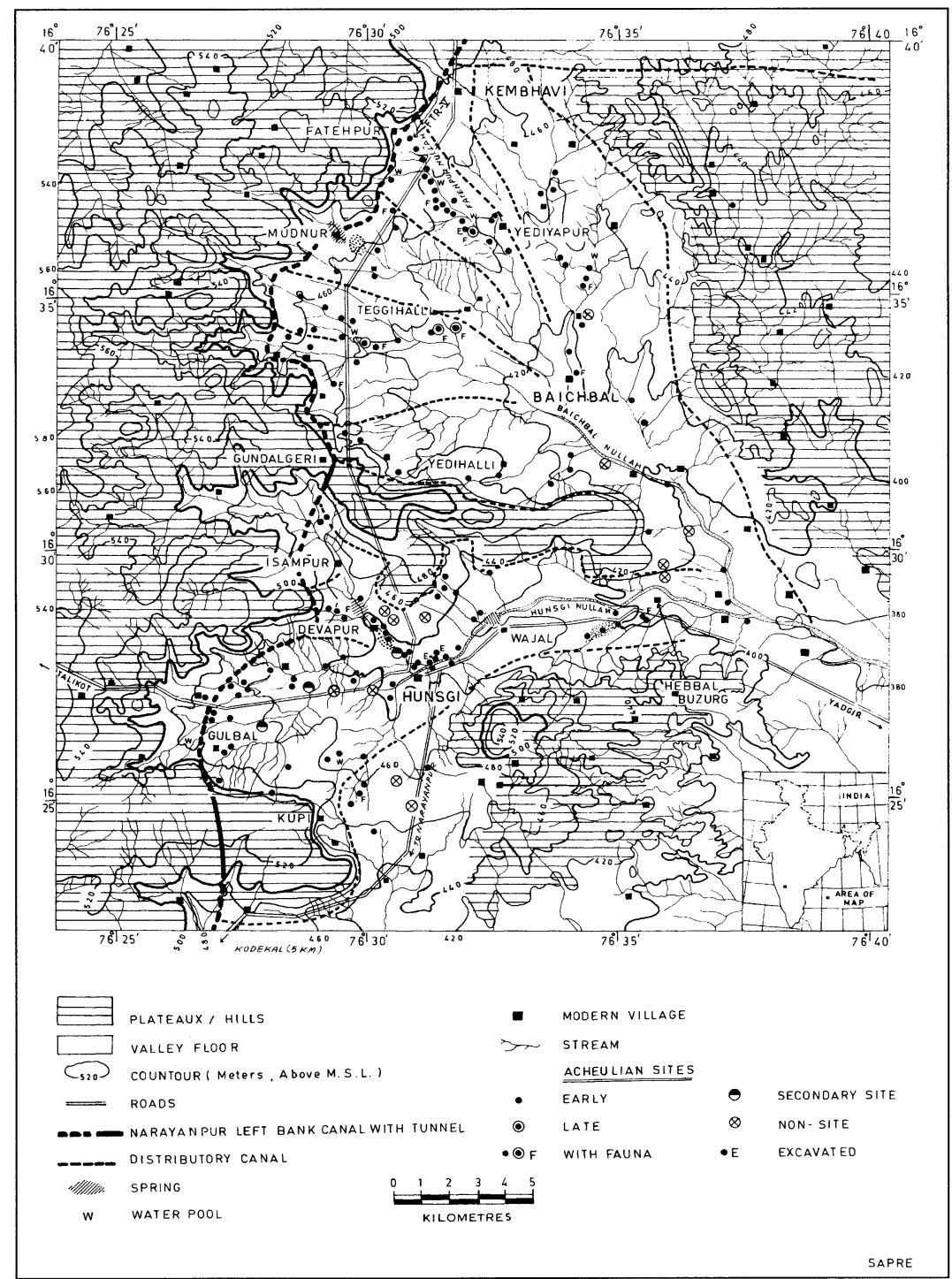

Figure 1. Map of Hunsgi and Baichbal Valleys Showing Acheulian Localities

The Isampur locality is in the northwest section of the Hunsgi Valley. 
posits indicates that seep spring activity may be assigned to the middle to late portions of the Middle Pleistocene (Szabo et al. 1990).

Archaeological investigations have been carried out in the Hunsgi and Baichbal Valleys since 1974, with surface survey and excavations revealing the presence of more than a hundred Acheulian occurrences and site complexes (e.g., Paddayya 1982, 1989) (see Figure 1). To better understand the relative integrity of the Lower Paleolithic occurrences and the degree to which they preserve behavioral information, formation process studies were initiated (Paddayya and Petraglia 1993, 1995; Jhaldiyal 1997). These context and artifact-based studies clearly showed that the western boundaries of the Hunsgi and Baichbal Valleys preserve relatively intact, nontransported localities, some buried under thick sedimentary units.

The Isampur site lies in the northwestern corner of the Hunsgi Valley and was originally discovered by Paddayya in 1983, as part of his survey of Lower Paleolithic occurrences (Figure 2). The site was part of a large modern burrow (measuring ca. $400 \times 300 \mathrm{~m}$ in extent) from which brown and black silt deposits ( 3 to $4 \mathrm{~m}$ thick) had been previously dug by the Irrigation Department for canal construction. At the time of initial discovery, only a small amount of Acheulian

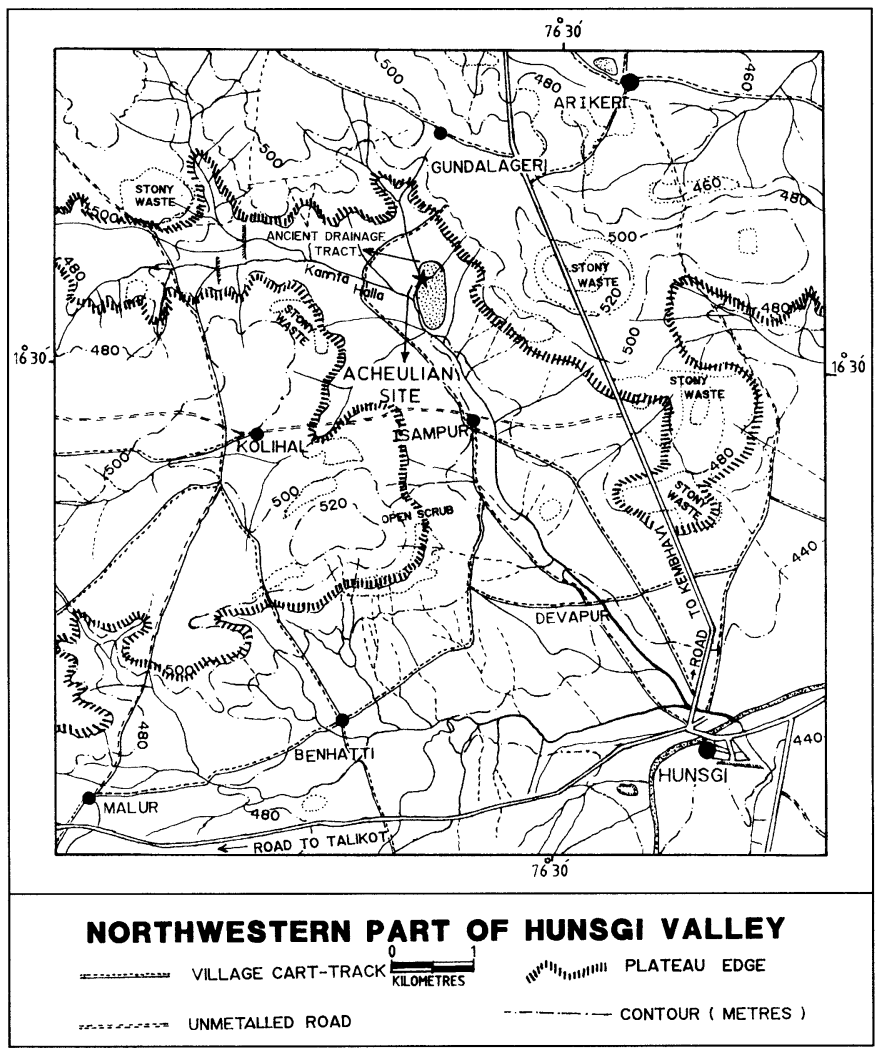

Figure 2. Location of Isampur Acheulian Locality in the Hunsgi Valley 
material was found on the surface, within remnant patches of a lower brown silt in the burrow. Two clusters were identified in 1983 (designated as Isampur Localities I and II), separated from each other by about $50 \mathrm{~m}$. The localities were small (measuring 10-15 m across), each yielding about 20 artifacts. Nearly all specimens were of limestone and included handaxes, cleavers, chopping tools, and flakes. These artifacts were found in a nonrounded condition, thereby indicating that the area may be a nontransported Acheulian locus.

As part of joint geoarchaeological studies in the Hunsgi and Baichbal basins, two of the authors (K.P. and M.P.) inspected the Isampur site area in 1994. An important observation made during the pedestrian survey was that the $3-4 \mathrm{~m}$ thick brown and black silts exposed by the Irrigation Department were part of an extensive body of sediment which filled up a shallow ancient drainage tract formed as the result of limestone erosion and collapse. This tract measured 300 to $400 \mathrm{~m}$ east-west and 700 to $800 \mathrm{~m}$ north-south. Acheulian Locality II at Isampur lay on the western edge of the drainage tract. The site was recognized to be much larger in extent than was observed in 1983; it extends over the shallow scrub-jungle-covered bed of a modern field watercourse (Figure 3). Rather than yielding just a few artifacts as identified earlier, new exposures indicated that the locality consisted of a large amount of Acheulian material comprising bifaces and debitage in farmers' fields and along the watercourse. The watercourse exposed limestone geological outcrops (the farmers' field boundaries are made of weathered limestone slabs) and hundreds of artifacts. The extent and density of artifactual material suggested that Isampur represented an Acheulian quarry.

Given the large amount of artifactual material eroding to the surface, the authors revisited the locality in 1997 for surface survey and test excavations. More than 120 artifacts were plotted on the surface of the farmers' fields (see Figure 3). A total of twelve one-meter-square trial pits and two trenches were placed after surface mapping. Tests revealed that the Acheulian level lay on the limestone pediment ( $470 \mathrm{~m}$ contour), subsequently buried by a meter-thick brown and black silt deposit. In most recent times, these sediments have been partly eroded away by the farmers' field channels, thereby exposing the Acheulian materials. The test excavations revealed that the Acheulian level roughly measured $80 \mathrm{~m}$ north-south and $70 \mathrm{~m}$ east-west. Much of the site area is occupied by the modern watercourse, but the site also covers the surrounding farmlands to some extent, particularly on the eastern side of the watercourse. Excavations of sedimentary deposits showed a stratigraphy consisting of a variably thick black silt, a compact brown silt, and an Acheulian assemblage consisting of limestone artifacts, all set in a matrix of hard calcrete-rich silt, resting directly on the limestone bedrock (Figure 4).

Although the limestone outcrop at Isampur is presently buried, major geological exposures occur throughout the valley, and exposures can be found within $1 \mathrm{~km}$ of the site ("stony waste" along plateau edges in Figure 2). The Late Proterozoic-age limestone is classified within the Bhima series of sedimentary rocks, in the Shahabad Formation (Radhakrishna and Vaidyanathan 


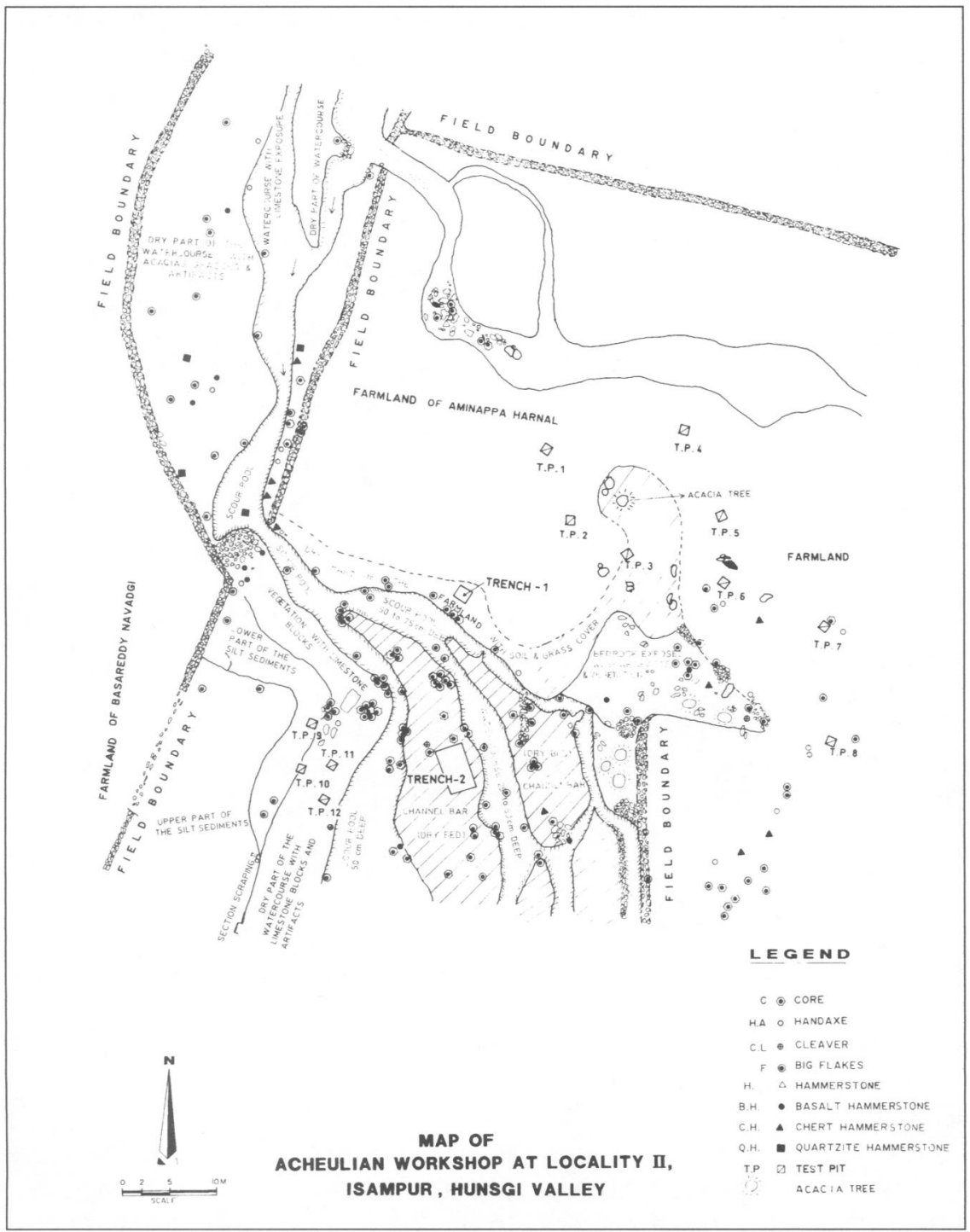

Figure 3. Map of Isampur Locality

Scale $=10 \mathrm{~m}$.

1994). The limestone beds dip gently towards the center of the Hunsgi-Baichbal basin, from 1 to $7^{\circ}$. The basin can be characterized as a typical Proterozoic Paruna-type basin. Paruna basins are sag basins which accumulate on eroded Archean-age landsurfaces. They contain a normal graded sequence, including basal conglomerates overlain by sandstones and black shales and capped with chemically precipitated limestone units. 


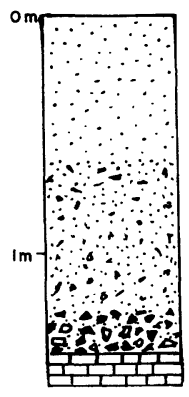

A
BLACK SILT

COMPACT BROWN SLT ( RICH IN CARBONATE,

ACHEULIAN LEVEL

BEDROCK ( LAMESTONE)

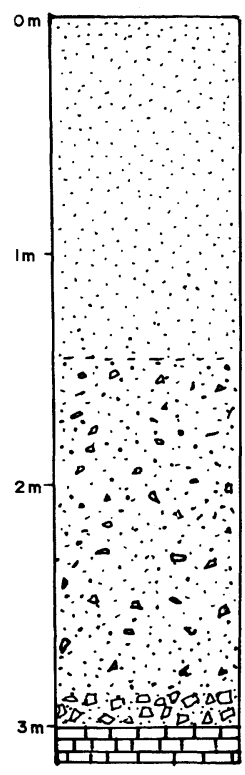

B
COMPACT

BLACK SILT

COMPACT BROWN SLT

( RICH IN CARBONATE

QUARTZ AND CHERT NODULES )

LIMESTONE CONCLOMERATE WITH KANKAR AS MATRIX

BEDROCK ( LIMESTONE)

Figure 4. Stratigraphic Sections of the Isampur Locality

The outlines of lower and upper bed surfaces $\left(\sigma_{1}\right)$ mark the cessation of chemical sedimentation. The laminations occurring between bedding surfaces are outlined by algal stomatolite growth and do not represent bed surfaces which can be split when struck by a hammer. Therefore, the lower and upper bed surfaces largely determine biface thickness. Gentle warping and sagging of the Paruna basin imparts to the limestone a foliation fabric or cleavage $\left(\sigma_{2}\right)$ which is nearly parallel to bedding ( 5 to $30^{\circ}$ ). Impact parallel to the bedding surface is captured and controlled by the all-penetrating cleavage fabric and is carried upward and outward through the lower and upper bedding surfaces. Mild extension of the limestones occurring during downwarping and crumpling of the basin edge along its borders have generated a plexus of master joint systems which can be mapped throughout the basin. The steeply inclined planes $\left(\sigma_{3}\right)$ and unsealed fractures dip from 55 to $90^{\circ}$ and control most of the drainage and runoff within the basin. These unsealed fracture surfaces break free during impact and create constraints on stone tool outlines. Although there are no distinct folds, a marked fault runs through the immediate study area at the Isampur quarry. The upthrown fault block is capped with a residuum of chert cobbles derived from the extensive chemical weathering of the overlying limestone. This residuum provided an extensive supply of hammerstone materials for the nearby quarries.

The petrofabric characteristics of the limestone are laminar in nature, homogenous in consistency, and generally highly siliceous. The limestone contains up to 18 percent pure silica, which is evenly dispersed through the limestone matrix. The fracture characteristics of most chemically precipitated 
limestones are conchoidal to subconchoidal. The limestone weathers in a highly predictable way producing joint-bounded bedding plane surfaces of variable thickness. Some of the horizontal beds are less resistant to weathering than others, thereby leading to separations between horizontally laid lithounits. The beds are interrupted by joint surfaces intersecting bedding at steep angles. Thus, once the limestone weathers from its primary outcrop, it often occurs in a tabular to blocky form, with thicknesses measuring from 2 to $20 \mathrm{~cm}$. Both tabular and blocky forms can be found within the Isampur quarry. The weathered form of the limestone and its excellent Hertzian flaking characteristics made it a favored material for stone tool manufacture (Figure 5). Limestone use for artifact manufacture varied from 1 to 100 percent for other localities situated in the Hunsgi and Baichbal Valleys; other preferred materials included quartzite, granite, dolerite, and schist (Paddayya and Petraglia 1993:Table 5). The quarry investigations indicate that mineralogical (i.e., beds, cleavage, joints) and weathering attributes (i.e., size of slabs, blocks) of the limestone influenced biface manufacture (Figure 6$)^{2}$

a)

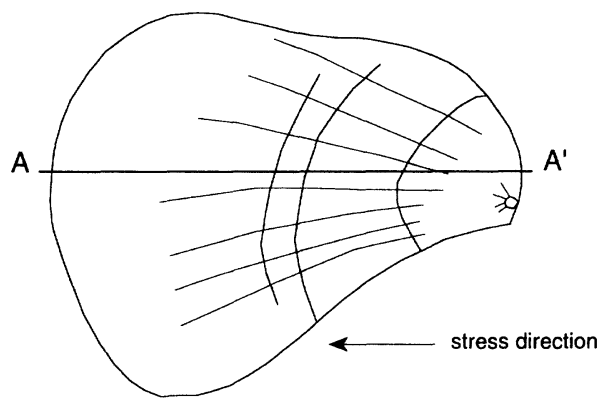

b)

c)

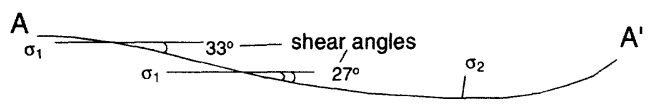

$\mathrm{A}$

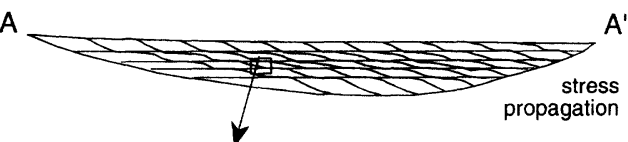

d)

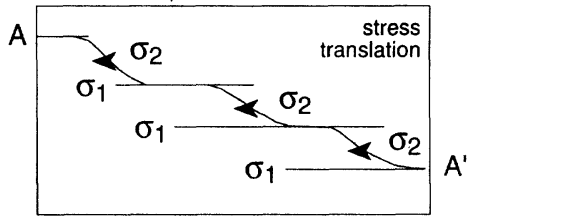

Figure 5. Flaking Mineralogy

(a) Schematic drawing of a flake in the Bhima limestone. (b) Cross section of the flake scar outline, showing shear angles developing between bedding planes $\left(\sigma_{1}\right)$ during the propagation of stress through the rock. (c) Cross section showing the integration of bedding $\left(\sigma_{1}\right)$ and cleavage planes $\left(\sigma_{2}\right)$. (d) Detail of stress propagation, showing the development of the foliation flake up through the plane of cleavage and bedding. 


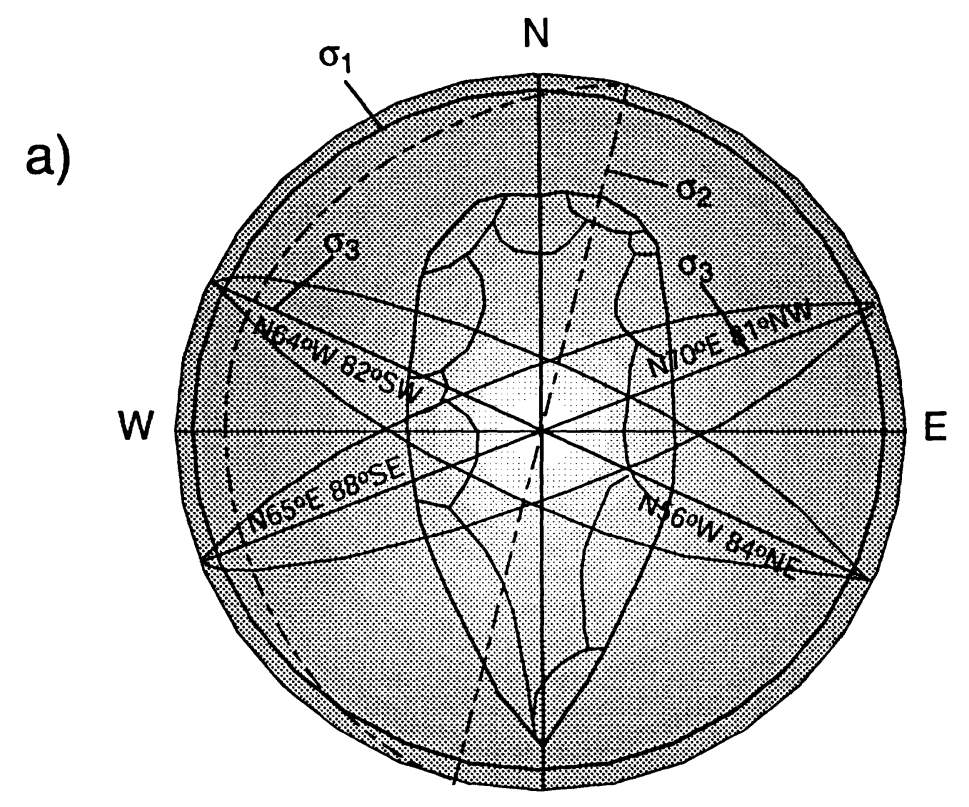

b)

\begin{tabular}{|c|c|c|}
\hline$\sigma_{1}$ plane of bedding & $\sigma_{2}$ plane of cleavage & $\sigma_{3}$ planes of jointing \\
\hline $\mathrm{N} 45^{\circ} \mathrm{W} 2^{\circ} \mathrm{SW}$ & $\mathrm{N} 42^{\circ} \mathrm{W} 10^{\circ} \mathrm{SW}$ & $\begin{array}{c}\mathrm{N} 73^{\circ} \mathrm{W} 90^{\circ} \mathrm{I} \\
\mathrm{N} 35^{\circ} \mathrm{W} 82^{\circ} \mathrm{NW}\end{array}$ \\
\hline $\mathrm{N} 40^{\circ} \mathrm{W} 1^{\circ} \mathrm{SW}$ & $\mathrm{N} 40^{\circ} \mathrm{W} 31^{\circ} \mathrm{SW}$ & $\begin{array}{l}\mathrm{N} 75^{\circ} \mathrm{W} 84^{\circ} \mathrm{SW} / \\
\mathrm{N} 25^{\circ} \mathrm{E} 84^{\circ} \mathrm{NW}\end{array}$ \\
\hline $\mathrm{N} 45^{\circ} \mathrm{W} 0^{\circ} \mathrm{SW}$ & $\mathrm{N} 39^{\circ} \mathrm{W} 29^{\circ} \mathrm{SW}$ & $\begin{array}{c}N 70^{\circ} \mathrm{W} 90^{\circ} \% \\
N 40^{\circ} \mathrm{E} 84^{\circ} \mathrm{NW}\end{array}$ \\
\hline $\mathrm{N} 90^{\circ} \mathrm{E} 4^{\circ} \mathrm{N}$ & $\mathrm{N} 90^{\circ} \mathrm{E} 30^{\circ} \mathrm{S}$ & $\begin{array}{l}\mathrm{N} 65^{\circ} \mathrm{W} 88^{\circ} \mathrm{NEI} \\
\mathrm{N} 45^{\circ} \mathrm{E} 86^{\circ} \mathrm{NW}\end{array}$ \\
\hline$N 0^{\circ} E 2^{\circ} \mathrm{W}$ & $\mathrm{N} 22^{\circ} \mathrm{E} 9^{\circ} \mathrm{NW}$ & $\begin{array}{c}\mathrm{N} 80^{\circ} \mathrm{W} 85^{\circ} \mathrm{NEI} \\
\mathrm{N} 22^{\circ} \mathrm{E} 90^{\circ}\end{array}$ \\
\hline
\end{tabular}

Figure 6. Mineralogy and Measurement of Bifaces

(a) Stereographic projection of structural controls on the manufacture of a typical Isampur handaxe. The circle labeled $\sigma_{1}$ represents the orientation of the bedding plane surface, and the circle labeled $\sigma_{2}$ represents the orientation of the cleavage plane (i.e., structural fabric imposed on the bed by folding). The two lines labeled $\sigma_{3}$ that run through the image of the handaxe represent intersecting master joint surfaces. (b) Typical geological measurements from the Isampur quarry site. Note that bedding surfaces are nearly horizontal, while cleavage surfaces are shallowly inclined and the master joints are nearly vertical. The relationship between these surfaces permits the extraction of well-defined slabs for use in handaxe and cleaver manufacture. 


\section{THE ISAMPUR ARTIFACT ASSEMBLAGE}

Table 1 provides a count of the Acheulian artifact assemblages encountered at Isampur. During surface survey, a range of exposed bifacial tools, cores, and hammerstones was noted and measured. To obtain a representative sample of the buried assemblage, Trench $1(2 \times 1.5 \mathrm{~m})$ was excavated in the sediments overlying the limestone bedrock. Trench 1 showed that the Acheulian assemblage occurred at the contact between the limestone bedrock and the brown sediments (Figures 7 and 8). With respect to the artifact types, the excavation showed that waste material (i.e., flakes, chunks, cores) was by far the most common artifact. No bifaces were found in the excavated context, but this is not unexpected since tools are much rarer than debitage throughout the locality. Trench 1 yielded limestone slabs (not tabulated in Table 1) measuring up to $100 \mathrm{~cm}$ in maximum length and up to $12 \mathrm{~cm}$ in thickness. (Slabs were also commonly observed in the modern watercourse.) Some of the limestone slabs in the trench were inclined 20 to $45^{\circ}$ and were no longer in a horizontal position (unlike their underlying beds), probably indicating hominid prying (Figure 8). These pried-up slabs sometimes exhibited steep negative flake scars. ${ }^{3}$ In Trench 1 there was positive evidence for refits, with at least 2 small flakes conjoining along the platform of a third large flake. ${ }^{4}$ Flaking of limestone was probably achieved with stone hammerstones, which total 27 at the site. The hammerstones were of various sizes (23 cobbles, 4 pebbles) and diverse, imported materials (basalt, $n=9$; chert, $n=9$; quartzite, $n=6$; dolerite, $n=1$; crystal quartz, $n=1$; limestone, $n=1$ ) (Figure 9; see Figures 7 and 8 for in situ hammerstones). Each of the major limestone artifact types from the surface and the excavations is fully described below.

TABLE 1

Isampur Artifact Classifications by Provenience

\begin{tabular}{|c|c|c|}
\hline Tool Type & Surface $n$ & Trench $1 n(\%)$ \\
\hline Handaxe & 36 & - \\
\hline Cleaver & 7 & - \\
\hline Core (block) & 9 & $11 \quad(4)$ \\
\hline Core (bifacial) & 4 & $1 \quad(.5)$ \\
\hline Core (radial) & 1 & - \\
\hline Flake & 29 & $251 \quad(90)$ \\
\hline Chunk & - & $11 \quad(4)$ \\
\hline Hammerstone & 23 & $4(1.5)$ \\
\hline Total & $\overline{109}$ & $\overline{278(100)}$ \\
\hline
\end{tabular}

Note: The surface count is neither complete nor representative but is meant to convey the range of artifact types that may be identified. The excavated Trench 1 data are representative of what a test in the quarry pediment may contain. 


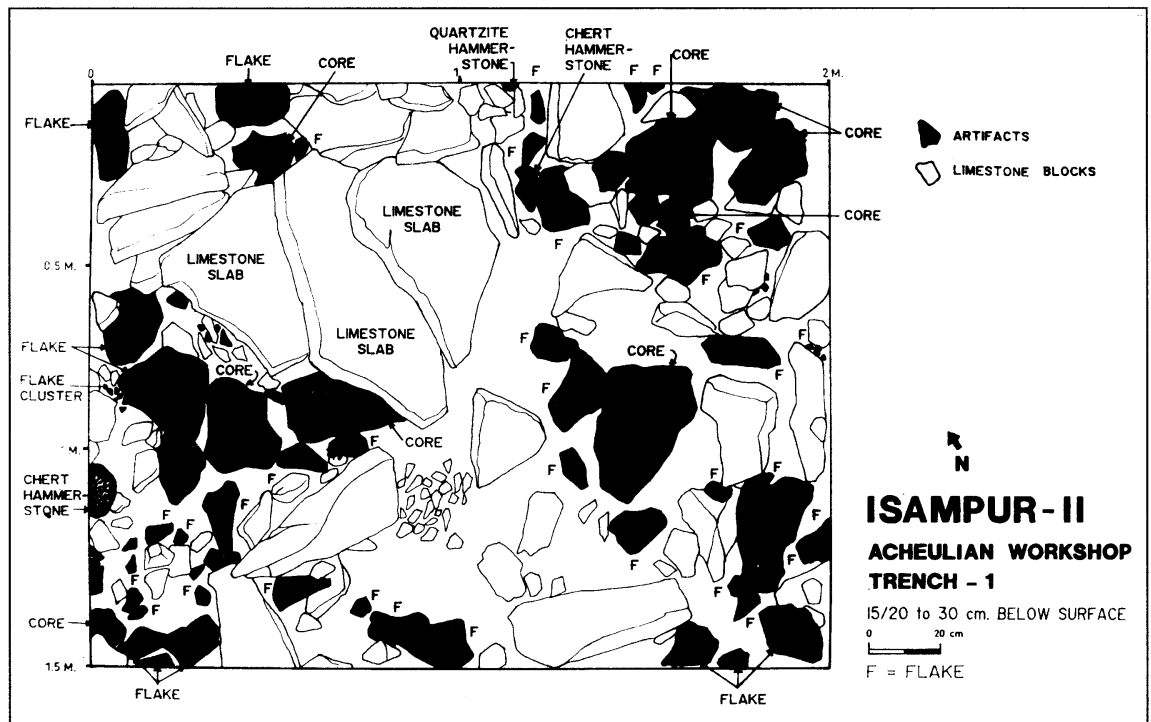

Figure 7. Limestone Blocks and Acheulian Artifacts Exposed 15/20 to $30 \mathrm{~cm}$ below the Surface in Trench 1

Scale $=20 \mathrm{~cm}$.

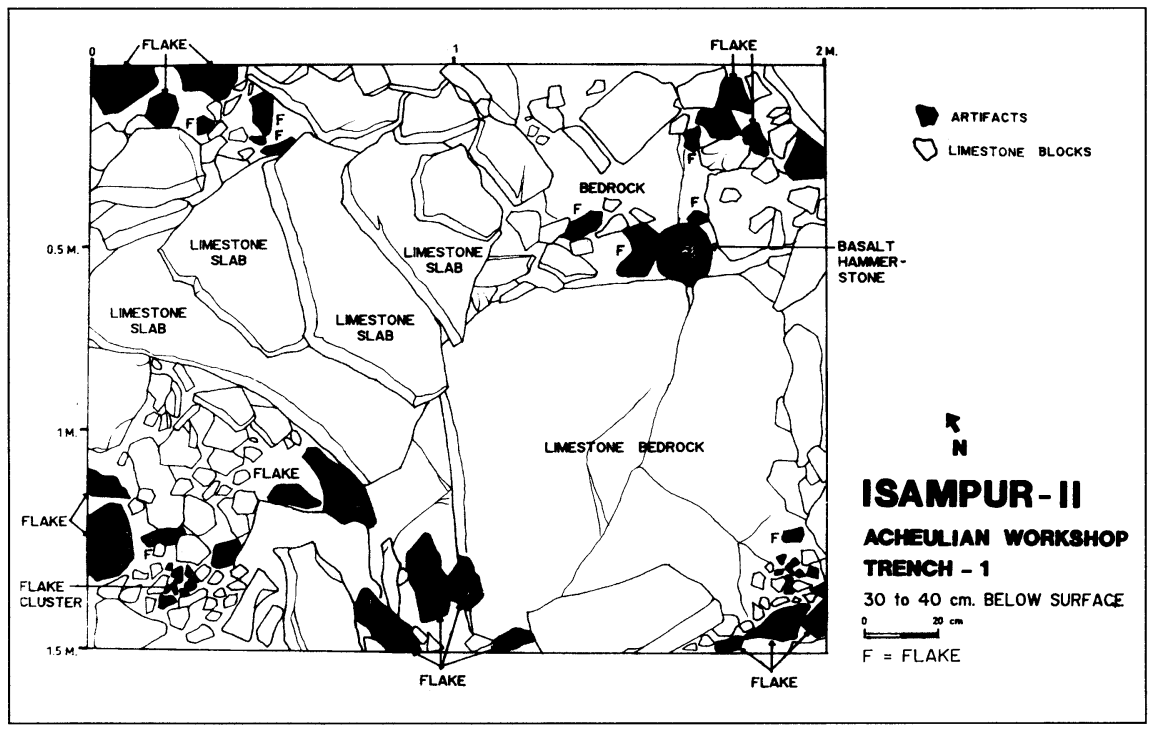

Figure 8. Limestone Blocks and Acheulian Artifacts Exposed 30 to $40 \mathrm{~cm}$ below the Surface in Trench 1

Scale $=20 \mathrm{~cm}$. 

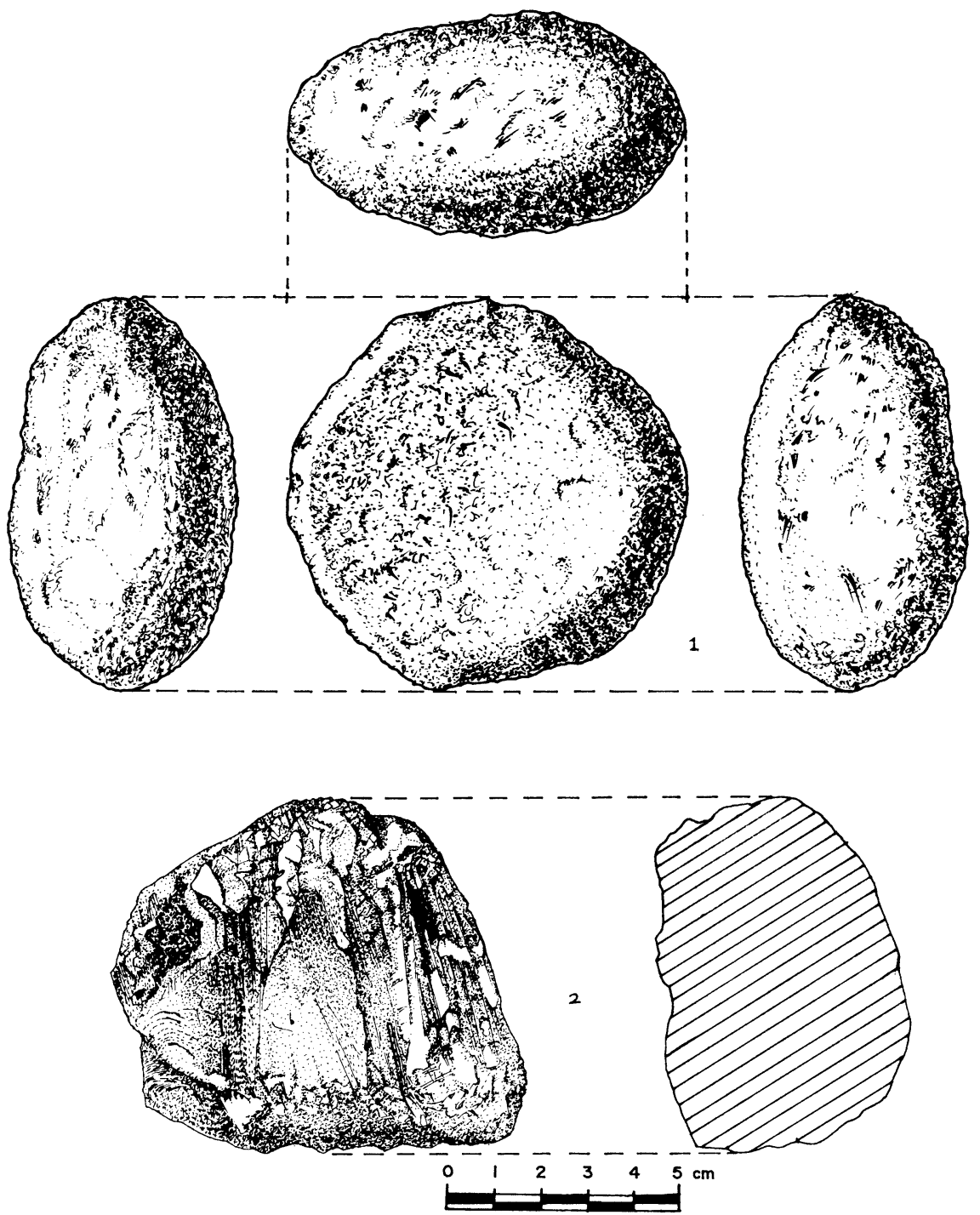

Figure 9. Hammerstones: (1) Dolerite and (2) Crystal Quartz

\section{Handaxes}

Thirty-three of the 36 handaxes were whole, and of the whole ones, lengths ranged from 10 to $26 \mathrm{~cm}$ (Figure 10). With respect to shape (Roe 1964, 1968), most handaxes fell within a range classifiable as ovate and double-pointed, as 28 of the 33 whole handaxes (85 percent) had $\mathrm{L}_{1} / \mathrm{L}$ values between 0.351 and 0.550 ( 5 were narrow, triangular to lanceolate $[\leq 0.350]$ and none were broad $[\geq 0.551])$. While the majority of handaxes may be classified as ovate and doublepointed, they may be subdivided as narrow-blunt and narrow-pointed. The thick- 
ness-to-breadth $(\mathrm{Th} / \mathrm{B})$ measurement, often taken as a measure of flatness, or "refinement" (Roe 1968), ranged from 0.3 (thinnest) to 0.7 (thickest) (Figure 11). The average $\mathrm{Th} / \mathrm{B}$ was 0.48 , although there was an unusual bifurcation, with peaks at 0.4 and 0.5 . Handaxe attributes were closely related to petrofabric attributes of the limestone (Figure 12).

All 36 handaxes were made on tabular slabs, with none produced on flakes. All handaxes were fashioned parallel to bedding, with edge flaking placed subparallel to oblique to the beds. All handaxes preserved some percentage of cortical bedding on their surface with a range of 5 to 35 percent, most falling between 15 and 25 percent. Since cortical bedding was preserved on two sides of 25 of the handaxes ( 70 percent), the thickness of the original weathered limestone slab could be measured; thicknesses of slabs ranged from 3 to $7 \mathrm{~cm}$, with an average thickness of $4.5 \mathrm{~cm}$. While many of the handaxes had proximal and distal ends bounded by joints, the tip sometimes was formed by a cleavage or foliation scar subparallel to bedding, thus forming a small bit reminiscent of a cleaver bit (however the bits of cleavers were entirely different in shape and size, as discussed later). These observations clearly indicate that handaxes cannot be thinned by flaking parallel to bedding. Chemical limestones are homogeneous and cannot be split through bedding planes. Therefore, the cessation of chemical sedimentation creates the lower and upper bedding surfaces, which appear on the dorsal and ventral surfaces of the handaxes.

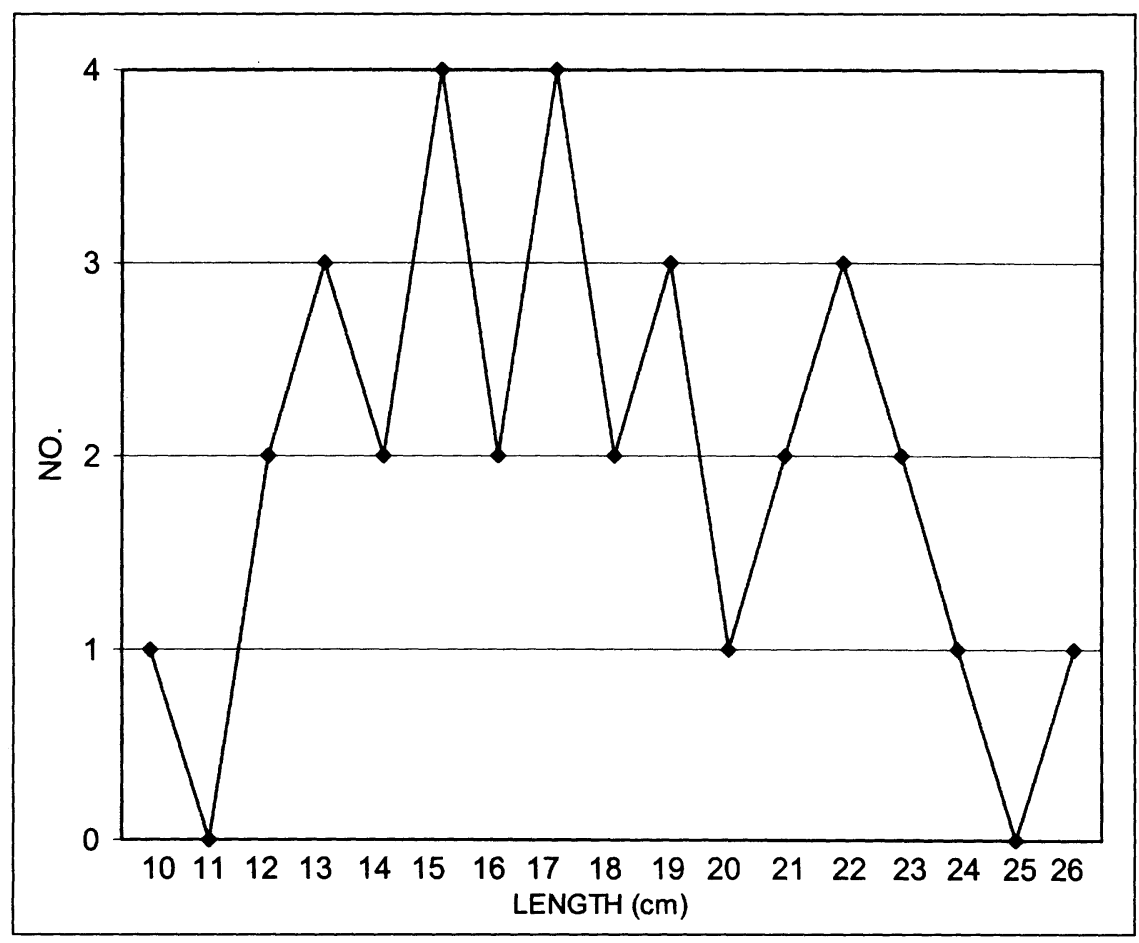

Figure 10. Handaxe Lengths 


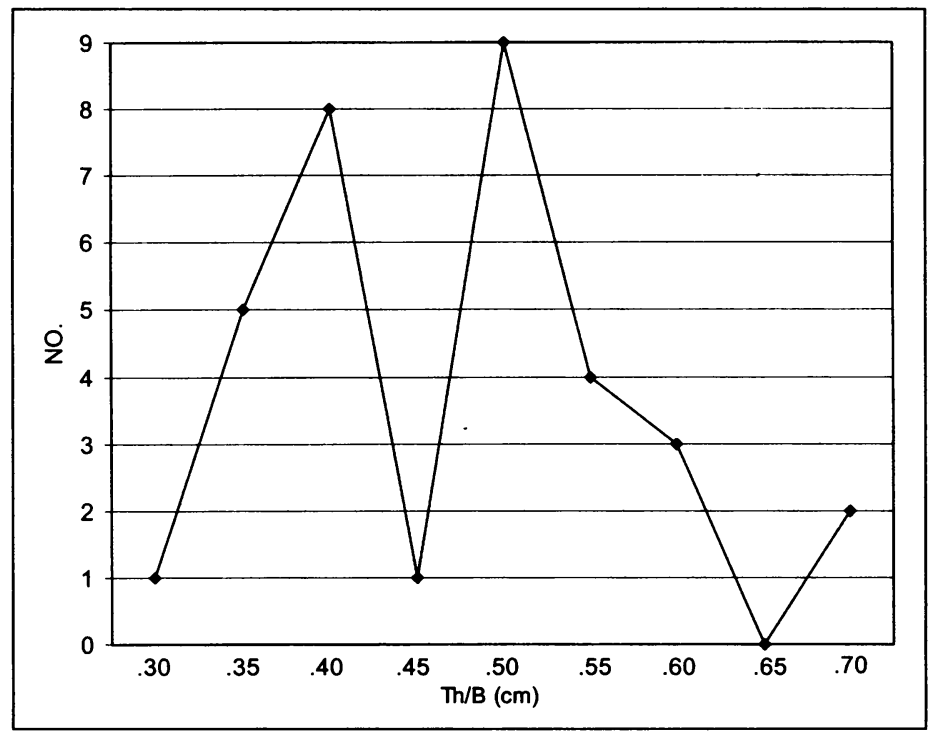

Figure 11. Thickness to Breadth (Th/B) Ratio for Handaxes
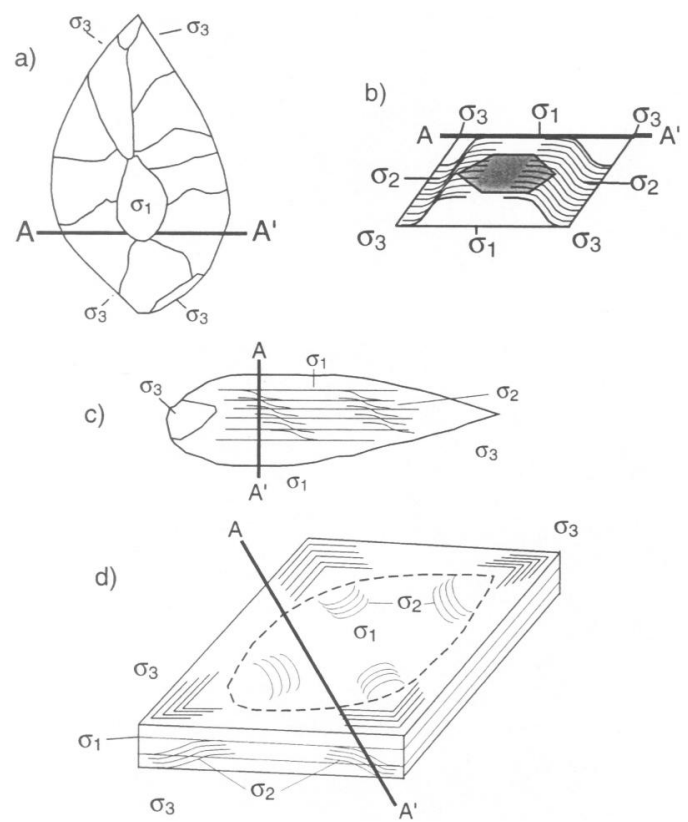

Figure 12. Mineralogy of a Handaxe

(a) Dorsal view of a typical handaxe, showing the bedding $\left(\sigma_{1}\right)$ and jointing $\left(\sigma_{3}\right)$ relationship to the handaxe form. (b) Cross section along A-A ${ }^{1}$, showing the trapezoidal outline of the handaxe and the intersection of cleavage $\left(\sigma_{2}\right)$. (c) Side view of the handaxe, showing cleavage planes $\left(\sigma_{2}\right)$ rising through the bedding surfaces $\left(\sigma_{1}\right)$ that are parallel to the dorsal and ventral sides of the handaxe. (d) Plane view of the handaxe in a jointed block $\left(\sigma_{3}\right)$ of limestone, as well as the orientation of structural fabric within the block. 


\section{Cleavers}

Six of the 7 cleavers were made oblique to subparallel to a bedding plane, with 1 cleaver made on a slab parallel to bedding (Figure 13). The 6 cleavers made oblique and subparallel to bedding were large side-struck flakes (thus not made on tabular slabs as were handaxes). Cleaver lengths (as measured

a)
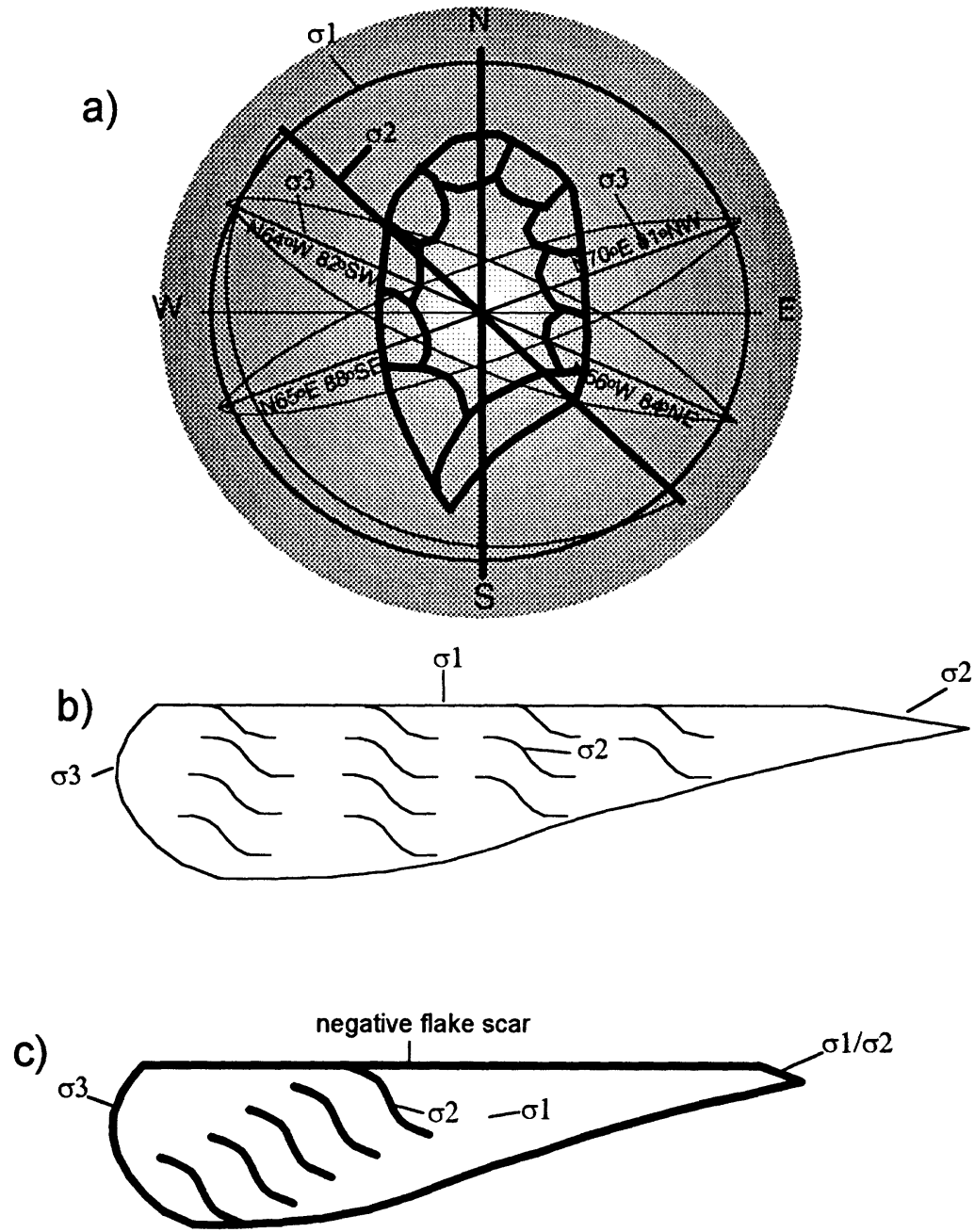

Figure 13. Mineralogy of a Cleaver

(a) Stereographic projection of structural controls on the manufacture of a typical Isampur cleaver. The circle labeled $\sigma_{1}$ represents the orientation of the bedding plane surface, and the circle labeled $\sigma_{2}$ represents the orientation of the cleavage plane (i.e., structural fabric imposed on the bed by folding). The two lines labeled $\sigma_{3}$ that run through the image of the cleaver represent intersecting master joint $\left(\sigma_{3}\right)$ surfaces. (b) Cross-sectional view of a cleaver made from a flake parallel to the bedding plane $\left(\sigma_{1}\right)$. In this case, the cleaver bit is a cleavage plane $\left(\sigma_{2}\right)$; the distal end is bounded by a joint $\left(\sigma_{3}\right)$. (c) Common cleaver form, where a cleaver is made from a flake oblique and subparallel to bedding. The cleaver bit is either the bedding plane or a bedding/cleavage $\left(\sigma_{\sigma} / \sigma_{2}\right)$ intersection; proximal and lateral surfaces may show conjugate joint $\left(\sigma_{3}\right)$ scars. The dorsal surface is the intersection of bedding and cleavage, or a negative flake scar. The ventral surface is always a positive flake scar. 
from flake platform to distal termination) ranged from 8 to $16 \mathrm{~cm}$, with an average length of $11 \mathrm{~cm}$. The widths (i.e., between lateral edges of the flakes) ranged from 13 to $20 \mathrm{~cm}$, with an average width of $16 \mathrm{~cm}$. The thicknesses ranged from 3 to $5 \mathrm{~cm}$, with an average of $4 \mathrm{~cm}$. Thus, on average, these side-struck flake cleavers had widths greater than lengths, with a length-to-width ratio of 0.64 $\mathrm{cm}$. All 7 cleaver bifaces preserved joint and cleavage surfaces on their bits and butts, a characteristic indicative of predicted flaking to produce a certain morphology which would intersect with mineralogical attributes. Four had joint or cleavage surfaces on the bits, and single examples had joints preserved on the bit and butt, on a lateral edge, and on the butt.

\section{Cores}

Of the 26 cores or core segments tabulated, three main types were distinguished based on their sizes and shapes; they can be categorized as block, bifacial, and radial, in order of decreasing abundance (Tables 1 and 2). Block cores were wide and thick (average $\mathrm{Th} / \mathrm{B}$ ratio of 0.78 ) (Figure 14) compared to bifacial cores which tended to be thinner relative to width (average $\mathrm{Th} / \mathrm{B}$ ratio of 0.39 ). Of the 16 whole cores, all preserved a relatively high percentage of cortical bedding, ranging from 35 to 70 percent, with an average of 51 percent. Nearly all of these cores preserved cortical bedding on two opposite sides, sometimes approximating their original clast form.

Block cores had an average thickness of $13.5 \mathrm{~cm}$ for those that preserved cortical bedding on opposite surfaces (twice as thick as bifacial cores). Nega-

TABLE 2

Core Attributes

\begin{tabular}{lcccccc}
\hline Type & $\begin{array}{c}\text { Length } \\
(\mathrm{cm})\end{array}$ & $\begin{array}{c}\text { Width } \\
(\mathrm{cm})\end{array}$ & $\begin{array}{c}\text { Thickness } \\
(\mathrm{cm})\end{array}$ & $\begin{array}{c}\text { No. } \\
\text { Flake } \\
\text { Scars }\end{array}$ & $\begin{array}{c}\text { Cortical } \\
\text { Bed/ } \\
\text { No. Sides }\end{array}$ & $\begin{array}{c}\% \\
\text { Cortical } \\
\text { Bed }\end{array}$ \\
\hline Blocky & 34 & 32 & 12 & 6 & yes/2 sides & 40 \\
& 34 & 24 & 17 & 8 & yes/2 sides & 40 \\
& 33 & 22 & 15 & 6 & yes/2 sides & 35 \\
& 33 & 15 & 16 & 6 & yes/2 sides & 60 \\
& 28 & 12 & 16 & 6 & yes $/ 1$ side & 50 \\
& 25 & 12 & 13 & 4 & yes/2 sides & 60 \\
& 24 & 21 & 14 & 4 & yes/2 sides & 50 \\
& 19 & 10 & 8 & 8 & yes/1 side & 50 \\
& 18 & 18 & 13 & 5 & yes/2 sides & 40 \\
Bifacial & 18 & 12 & 8 & 6 & yes/2 sides & 50 \\
& 35 & 17 & 5 & 8 & yes/2 sides & 50 \\
& 31 & 13 & 9 & 10 & yes/2 sides & 50 \\
& 27 & 21 & 9 & 10 & yes/2 sides & 75 \\
& 25 & 18 & 5 & 10 & yes/2 sides & 50 \\
Radial & 20 & 16 & 5 & 8 & yes/2 sides & 50 \\
& 25 & 23 & 6 & 35 & yes/2 sides & 70 \\
\hline
\end{tabular}



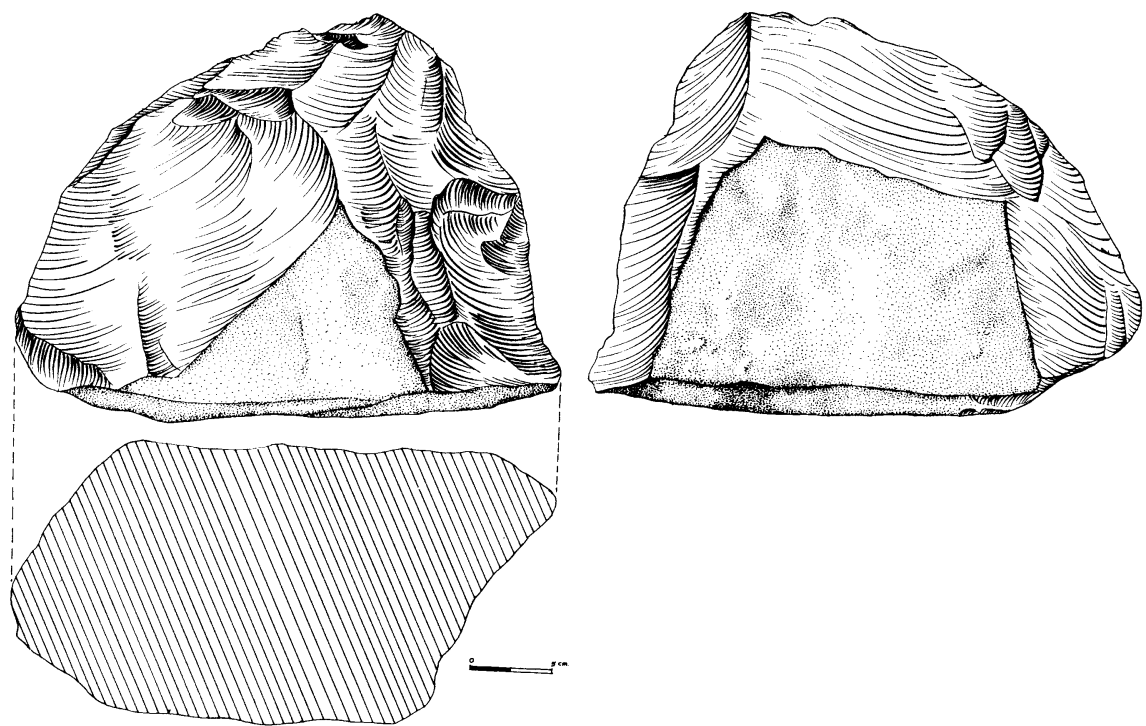

Figure 14. Limestone Block Core from Trench 1

Scale $=5 \mathrm{~cm}$.

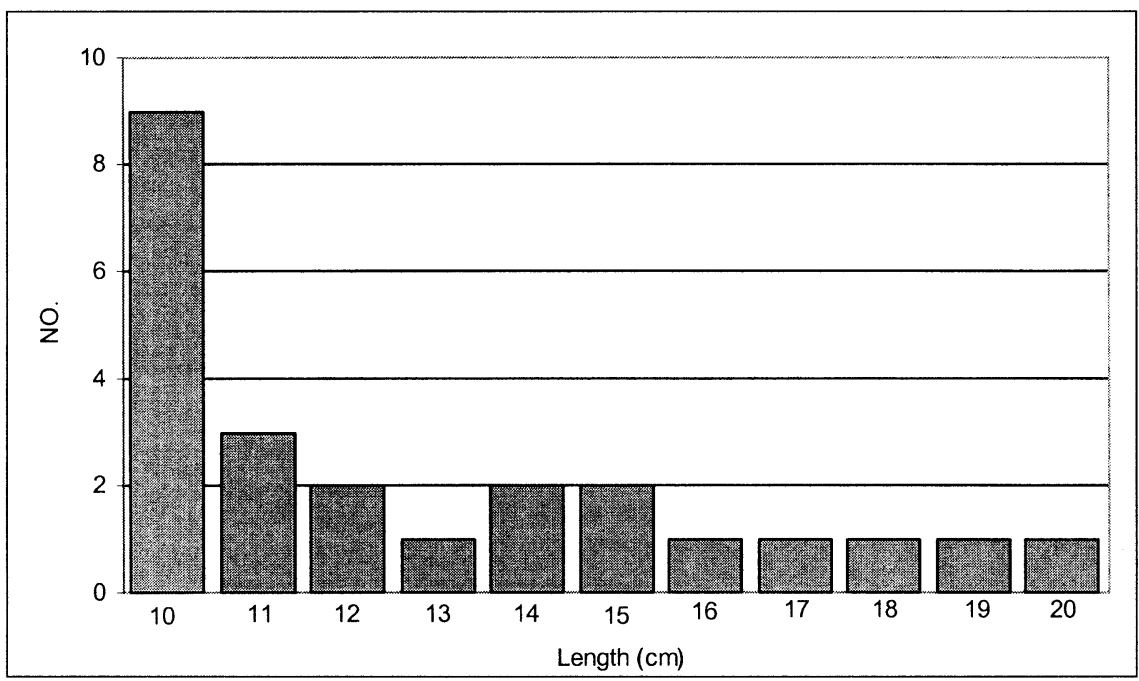

Figure 15. Size Range of Negative Flake Scars $(\geq 10 \mathrm{~cm})$ on Cores

tive scars preserved on the block cores appear to be the result of flaking for cleaver production. On block cores, negative flake scars showed that large flakes $\geq 10 \mathrm{~cm}$ could be derived (Figure 15). These large flakes appear to have been well planned, as the cores do not show many other negative flake scars (averaging 6 negative flake scars per core). The flakes were struck subparallel and oblique to bedding. Joint surfaces were present at the terminations of the nega- 
tive flake scars on 6 of the block cores. Oftentimes negative flake scar lengths (i.e., distance from platform to distal termination) were shorter than the lateral edge widths. This results in a length-to-width ratio of 0.87 for negative flake scars $\geq 10 \mathrm{~cm}$.

The 5 bifacial cores showed some degree of variability in their sizes, with a wide range in lengths ( 20 to $35 \mathrm{~cm}$ ) and thicknesses of $5 \mathrm{~cm}$ and $9 \mathrm{~cm}$, respectively. Flake scars were relatively few, averaging about 9 per bifacial core. Like handaxes, the 5 bifacial cores were all made parallel to bedding, with cortical bedding surfaces preserved on both sides. The bifacial cores which measured $5 \mathrm{~cm}$ in thickness approximated handaxe thicknesses. However, the lengths of the bifacial cores tended to be greater. If these were initial forms for handaxe manufacture, then length and width measurements would have decreased with further reduction and shaping.

The single radial core was steeply flaked on a 6 -cm-thick tabular slab (similar to bifacial cores) and extensively flaked $(n=35)$ along joint surfaces producing a circular plane form $(25 \times 23 \mathrm{~cm})$. A large percentage of cortical bedding (ca. 70 percent) was preserved on its dorsal and ventral surfaces. This is a unique specimen for the Hunsgi and Baichbal sites; its systematic flaking around the perimeter of the piece appears to indicate some degree of preparation.

\section{Flakes}

A large absolute number of artifacts from the Isampur quarry were flakes. Most of the flakes recovered from Trench 1 were small: 50 percent were less than $5 \mathrm{~cm}$ in maximum length (Table 3). While most of the flakes fell in the small range, large flakes were also present: 29 percent measured up to $10 \mathrm{~cm}$ in size (Figure 16), and 21 percent were larger than $10 \mathrm{~cm}$ (Figure 17), with 2 very large flakes measuring 35 and $36 \mathrm{~cm}$, respectively. While the percentage of small flakes was high, evidence suggested postdepositional sorting. The greatest number of flakes fell within the $3 \mathrm{~cm}$ size, with lower numbers in the 1-2 $\mathrm{cm}$ range (Figure 18), suggesting that some portion (but not all) of the smallest of items was winnowed from the site area, as is commonly evidenced in assemblages subjected to water flow (Schick 1986; Petraglia and Potts 1994).

A total of 36 percent of the flake assemblage retained cortical bedding, a relatively high percentage. The small flakes generally had a lower percentage

TABLE 3

Flake Attributes, Trench 1

\begin{tabular}{crc}
\hline Length $(\mathrm{cm})$ & $n(\%)$ & \% Cortex \\
\hline $1-5$ & $127(50)$ & 15 \\
$6-10$ & $73(29)$ & 40 \\
$11-15$ & $17(7)$ & 53 \\
$16-20$ & $23(9)$ & 87 \\
$21-25$ & $5(2)$ & 80 \\
$26-30$ & $4(2)$ & 100 \\
$>30$ & $2(1)$ & 100 \\
\hline
\end{tabular}



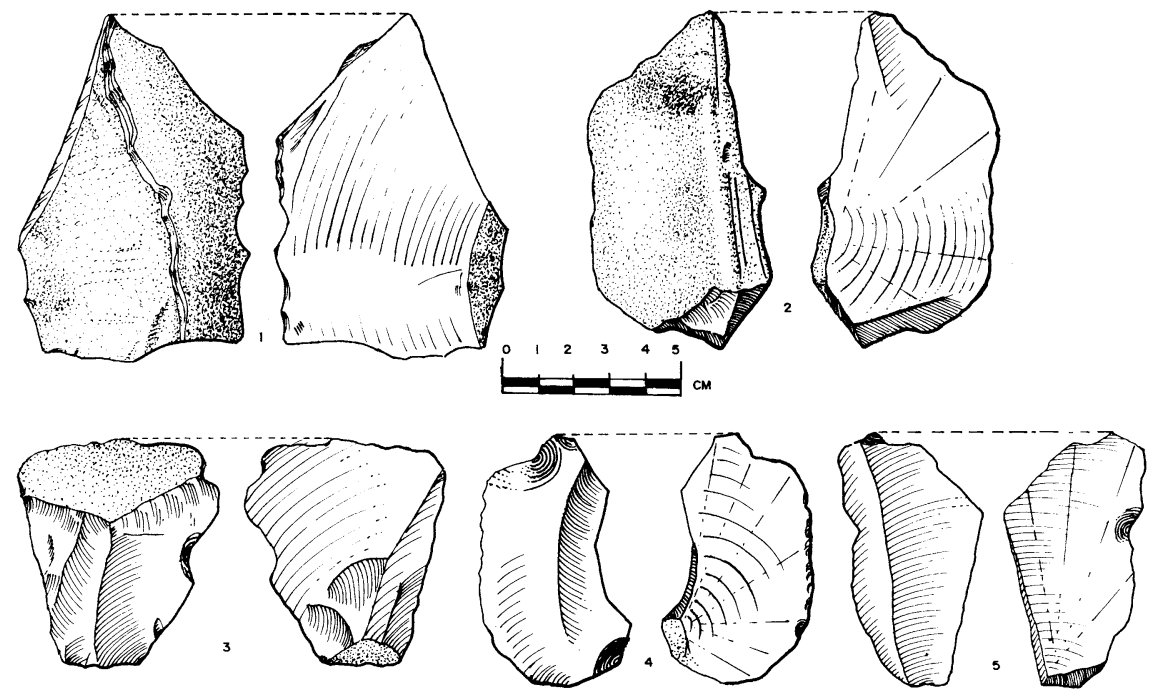

Figure 16. Limestone Flakes from Trench 1

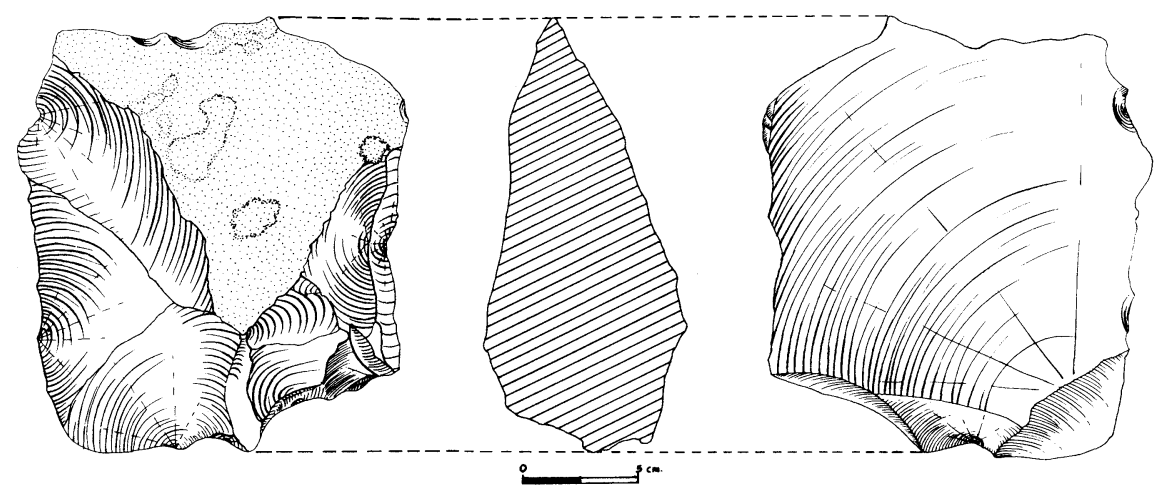

Figure 17. Large Limestone Flake from Trench 1

Scale $=5 \mathrm{~cm}$.

of cortical bedding, whereas large flakes $(\geq 10 \mathrm{~cm})$ almost always retained cortical bedding. This situation likely parallels the core reduction sequence. The largest cortical flakes, on the outermost part of the cores, would have been removed first. Once this was accomplished, smaller ranging flakes with less cortex could have been obtained.

For flakes $\geq 10 \mathrm{~cm}$, many had widths that were greater than lengths (distance from platform to distal termination). Most length-to-width ratios fell between 0.5 to 1.0 , with many falling between 0.5 to 0.7 (Figure 19). This fact complements the side-struck cleaver data, which indicated a length-to-width ratio of 0.64. While large flakes shared similar length-to-width ratios, there were two subtypes-outermost decortication flakes and inner flakes. The outermost flakes often shared a certain morphology, with platforms smaller than distal 


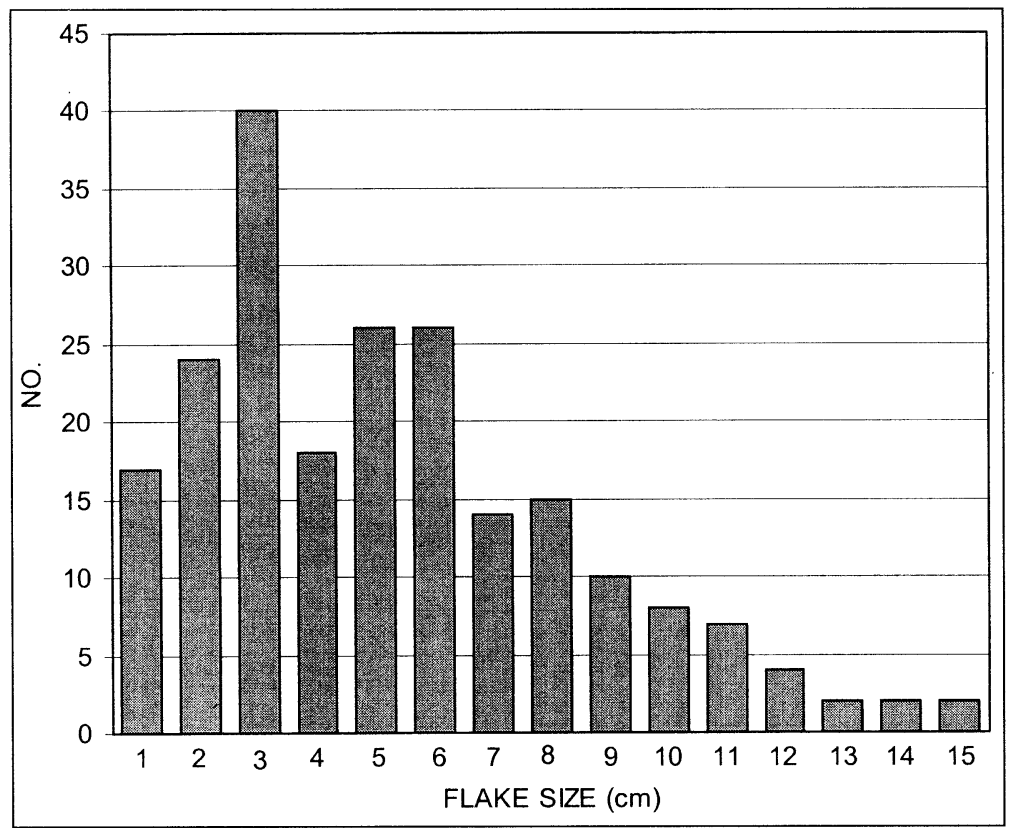

Figure 18. Flake Size Range (Maximum Length) from Trench 1

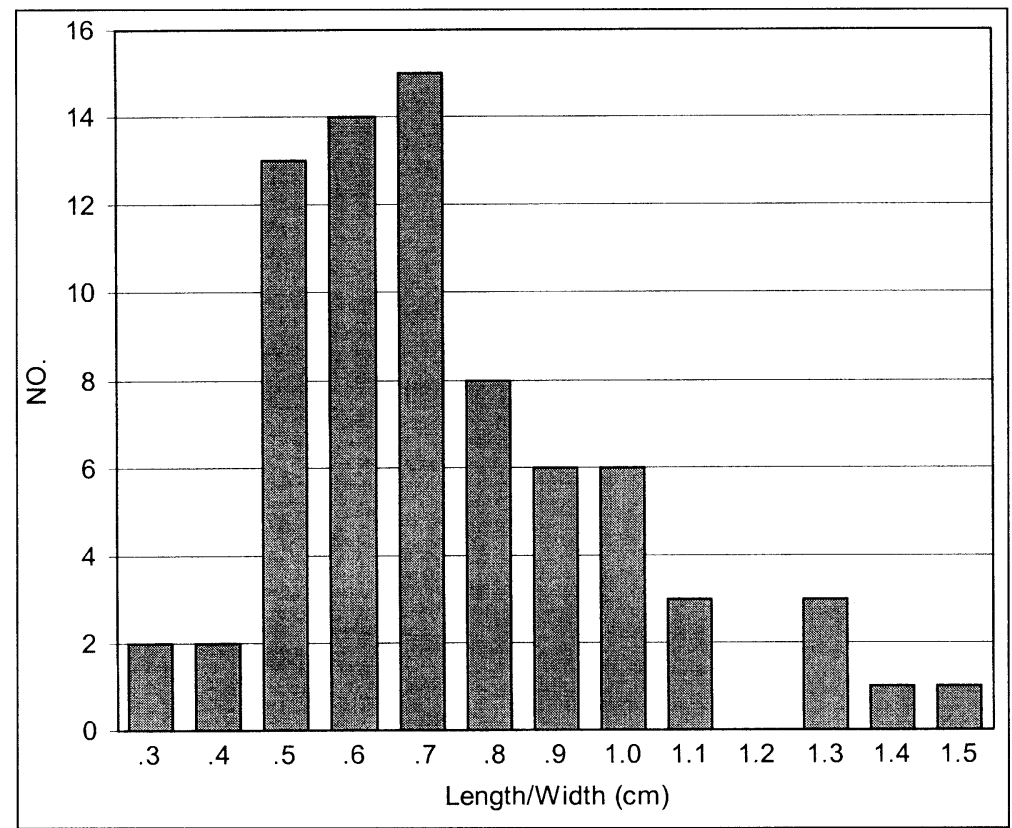

Figure 19. Length to Width Ratio for Flakes $\geq 10 \mathrm{~cm}$ 
TABLE 4

Attributes of Decortication flakes ( $\geq 10 \mathrm{~cm}$ )

\begin{tabular}{ccc}
\hline $\begin{array}{c}\text { Platform } \\
\text { Area }(\mathrm{cm}) \\
(\mathrm{L} \mathrm{x} \mathrm{W})\end{array}$ & $\begin{array}{c}\text { Distal } \\
\text { Area }(\mathrm{cm}) \\
(\mathrm{L} \mathrm{x} \mathrm{W})\end{array}$ & $\begin{array}{c}\text { Cortical } \\
\text { Bed } \\
\text { Thickness } \\
(\mathrm{cm})\end{array}$ \\
\hline 3 & 102 & 15 \\
3 & 160 & 12 \\
4 & 225 & 12 \\
6 & 117 & 9 \\
20 & 108 & 14 \\
25 & 168 & 9 \\
30 & 190 & 18 \\
32 & 252 & 7 \\
36 & 70 & 10 \\
40 & 84 & 14 \\
40 & 128 & 14 \\
48 & 160 & 14 \\
72 & 108 & 13 \\
81 & 504 & 13 \\
105 & 126 & 15 \\
130 & 286 & 11 \\
\hline
\end{tabular}

terminations. The size or area of the platforms and distal terminations varied significantly, with platforms measuring between 3 and $130 \mathrm{~cm}^{2}$ and distal ends measuring between 70 and $504 \mathrm{~cm}^{2}$ (Table 4). The large flakes were likely struck from thick, block cores, as their cortical bed thickness measured, on average, $12.5 \mathrm{~cm}$.

\section{DISCUSSION AND CONCLUSIONS}

The Acheulian site of Isampur represents a unique archaeological resource on the Indian subcontinent and a rare site type for the Lower Paleolithic of the Old World in general. This is the first Acheulian quarry to be identified in India, although it is predicted that others will be located in the Hunsgi and Baichbal Valleys once this limestone outcrop, now buried by later Pleistocene sediments, is traced through future survey and excavation work. ${ }^{5}$ The Isampur assemblage occurs at a limestone bedrock source, where weathered slabs of suitable sizes and shapes could be procured in plentiful quantity. The lack of artifact rounding, the large quantity of artifacts and their wide range of sizes, the existence of conjoinable artifacts, and artifact location within the limestone pediment and brown sedimentary deposits all converge to indicate that the Acheulian assemblage is nontransported. Some postoccupation sorting is probable, however, since relatively slow burial at a bedrock and pediment deposit is to be expected, and, in fact, there are signs that some of the smallest flakes $(<2 \mathrm{~cm})$ were winnowed from the site area or at least were subject to spatial rearrangement. 
The Isampur quarry contains a diversity of artifact types, including bifaces (handaxes, cleavers), waste products (cores, flakes, chunks), and hammerstones. The hammerstones, of various materials (basalt, chert, quartzite), were carried to the Isampur locality, as no material other than limestone occurs naturally at this spot. However, these other raw materials were obtainable within 1 $\mathrm{km}$ of the Isampur locality, and it is possible that the hammerstone materials may have been available closer to the site, occurring as gravels in nearby paleodrainages. The hammerstones vary in size and degree of battering, likely indicating that they were used during different stages of tool manufacture, with larger ones used as percussors to detach large flakes and smaller hammerstones used for biface shaping.

The Isampur locality provides an unprecedented situation for examining raw material selection processes, stone tool manufacturing methods, and resultant stone tool types. As documented by the following discussion, the Acheulian stone tool assemblage at Isampur appears to be the product of hominid choices and physical influences exerted by the limestone raw material.

With regard to settlement behaviors, the Isampur quarry is the product of hominid visitation to procure a desirable raw material. Hominids visited the outcrop to procure a highly siliceous limestone with excellent Hertzian flaking characteristics, in the form of weathered slabs useful for reduction to stone tools. Hominids targeted the Isampur locality for flaking and tool production, thereby disregarding many other places where limestone occurred in abundance in the Hunsgi and Baichbal Valleys. In addition to a desirable raw material, Isampur had a secure water supply in the form of a spring or seasonal ponds, which no doubt also provided faunal and floral resources. Hominids were thus drawn to Isampur as a consequence of a multiaspect resource situation, where a usable raw material and a favorable ecological setting co-occurred.

Once at the Isampur locality, hominids then employed certain flaking methods on weathered slabs of various sizes, but thin weathered slabs $(<3 \mathrm{~cm}$ in thickness) were never flaked. The dismissal of thin limestone slabs clearly indicates a preference for thicker clasts. Thicker tabular slabs of appropriate thickness were targeted, flaked, and sometimes pried from the limestone bedrock. Tabular slabs (whether already weathered from the outcrop or pried) were used to produce handaxes, whereas thicker limestone slabs were used to obtain flakes for the manufacture of side-struck cleavers. These observations indicate that hominids anticipated and targeted certain limestone slabs for production of specific tool types.

Handaxes were typically manufactured from tabular limestone slabs with a restricted thickness range (usually 4-7 cm), measurable as a consequence of still-preserved cortical bedding on dorsal and ventral sides of the bifaces. Handaxes from tabular slabs had symmetrically shaped lateral edges and convergent tips. The "bifacial cores" shared certain properties with handaxes, but they were not as clearly shaped. Both handaxes and bifacial cores were made parallel to bedding, and both were made on tabular slabs. As flakes were struck into the edge, they were placed obliquely into the bedding plane. During the 
handaxe manufacturing process, some apparently broke, often at the midsection or towards the tip, usually because of internal joint planes. This may parallel a situation seen at the Boxgrove Acheulian site in England, where bifaces broke from "endshock" during the manufacturing process (Austin 1994).

At Isampur, maximum handaxe length was often constrained by tabular slab length (Figure 20). Mineralogical attributes could be observed on proximal and distal ends of handaxes and occasionally on lateral edges. As a consequence, there was some degree of variation in handaxe lengths at Isampur (complementing variable handaxe lengths seen in other Acheulian assemblages, e.g., Crompton and Gowlett 1993; Gowlett and Crompton 1994). The Isampur data suggest that shorter bifaces may sometimes be smaller designs and not necessarily biface end products which were subject to continuous reduction. As further support of this suggestion, most of the shorter handaxes are trapezoidal in cross section. If larger bifaces had been subjected to repeated flaking and retouching, they would have become rectangular in cross section as a result of cleavage forces, but such forms do not exist in the assemblage. Thus, handaxe size parameters indicate that length alone should be not taken to represent a continuum of reduction; that is, caution should be exercised in assuming that shorter pieces represent reduced forms derived from once-lengthier bifaces (moreover, it cannot be assumed that handaxe size and morphology are directly related to temporal trends, a common practice in Indian Paleolithic studies [see Petraglia 1998]).
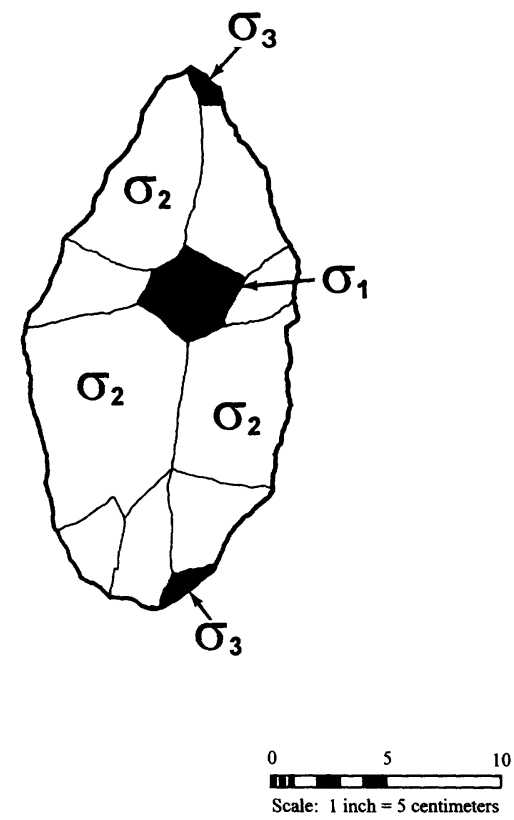

Figure 20. Isampur Handaxe Showing Mineralogical Attributes

The handaxe is made parallel to bedding, resulting in cortical bedding $\left(\sigma_{1}\right)$ at the center of the piece. The butt and tip show joint surfaces $\left(\sigma_{3}\right)$, and each flake is inclined into cleavage $\left(\sigma_{2}\right)$. 
While handaxe sizes vary within the quarry, these bifaces have similar gross shapes, classifiable as narrow ovate and bi-pointed, with a few displaying lanceolate shapes and none classifiable as broad types. At this point in this investigation, it is not clear whether handaxe shape relates to raw material constraints or imposed designs, or both. Indeed, there appears to be some degree of variability in handaxe shapes among the scores of Hunsgi and Baichbal Valley localities, and the Isampur quarry does not exhibit the entire array of potential handaxe shapes (see Paddayya 1982 for examples). More attention needs to be given to shaping characteristics and their potential sources of influence, but current evidence certainly shows that the limestone slabs were oriented and handaxes were manufactured using a standard reduction approach.

In contrast to handaxe manufacturing techniques, cleavers were predominately made from side-struck flakes (the distance from flake platform to distal termination was shorter than lateral edge width). The side-struck flakes are inferred to have been struck from block cores found in abundance at Isampur. The thickest limestone slabs $(8-20 \mathrm{~cm})$ were sought out by hominids so that flakes of appropriate size and shape could be derived. Once appropriate slab thicknesses were obtained, the outer surfaces of the slabs were flaked to prepare the core for striking. Flakes for cleaver production were then struck obliquely and subparallel to the bedding of the thick limestone cores and often were flaked so that the bit of the cleaver would intersect with cleavage or joint surfaces (Figure 21). This approach permits the dorsal side of the cleaver to be

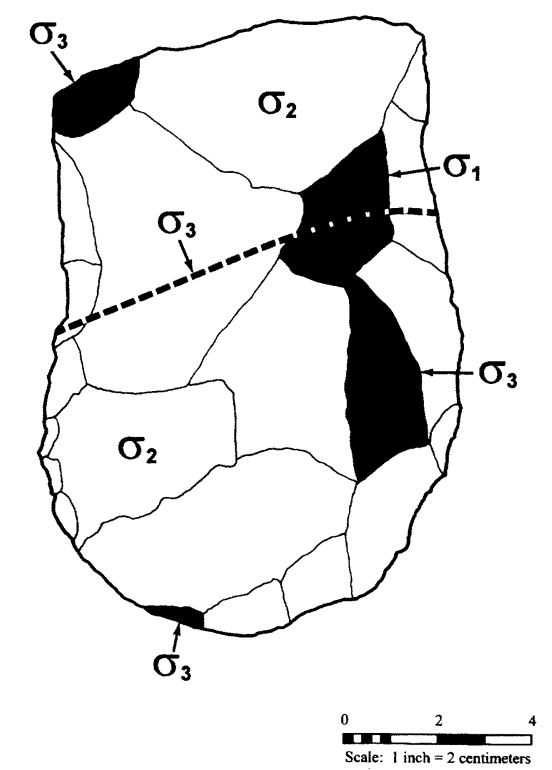

Figure 21. Cleaver from Mudnur X Locality Showing Mineralogical Attributes

The cleaver is a side-struck flake, resulting in a bedding plane which is oblique $\left(\sigma_{1}\right)$. The butt is bounded by a joint $\left(\sigma_{3}\right)$, and the bit is bounded by a joint $\left(\sigma_{3}\right)$ and a cleavage scar $\left(\sigma_{2}\right)$. At the midsection of the cleaver, an internal joint line $\left(\sigma_{3}\right)$ can be observed. 
either subparallel to cortical bedding or an actual cortical bedding surface, while the ventral surface is a bulb or flake scar along the foliation. This orientation permits the cleaver bit to end at a sharp intersection of the negative flake scar and cortical bedding or occasionally at the intersection of a foliation flake on bedding. In some cases, cleaver butts intersected with a joint or two converging or conjugate joint surfaces. Therefore, the stone tool manufacturer deliberately oriented the block before proceeding to produce a cleaver on a flake.

While we have hypothesized that handaxes and cleavers are two separable components of a stone tool manufacturing process, there is also evidence of a biface form which shares some attributes of both handaxes and cleavers (Figure 22). Several localities in the Hunsgi Valley contain bifaces that were produced parallel to bedding and are shaped like handaxes. However, these bifaces also exhibit a small, narrow cleavage or joint surface on the tip, reminiscent of a cleaver bit. These narrow bits have the appearance of bifaces which have been laterally or obliquely struck using a tranchent blow, but it is not clear if this bit was intentional. Thus this type may be defined as pieces which were made on tabular slabs with the perimeter retouch and shaping characteristic of handaxes, but which show narrow "bits" which are reminiscent of cleavers. Although mineralogical and morphological distinctions may be made between these forms and cleavers, the possibility cannot be discounted that the sharp and straight edge bits on both of these forms functioned in a similar manner.

While hominids applied particular methods to produce certain tool types (i.e.,
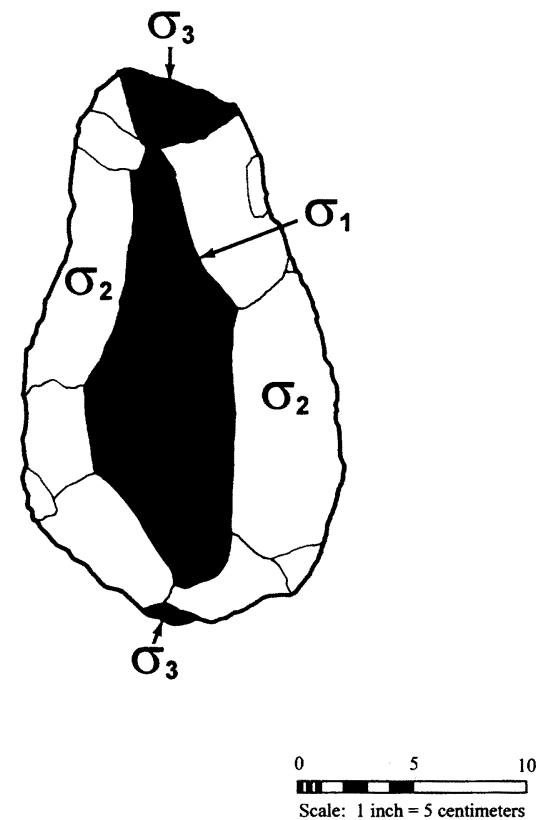

Figure 22. Biface from Hunsgi VI Locality

The biface is shaped and manufactured parallel to bedding $\left(\sigma_{1}\right)$, replicating handaxe attributes. However, note that the joint surface at the tip produces a narrow bit $\left(\sigma_{3}\right)$, reminiscent of a cleaver bit. 
handaxes, cleavers), the petrofabric attributes of the limestone probably played a role in conditioning the chosen production methods and resultant biface morphology, thus suggesting that similar styles of tools may, in part, result from the physical properties of the stone. For instance, the form of handaxes made from the Hunsgi and Baichbal Valley limestones is controlled by bed outline $\left(\sigma_{1}\right.$, thickness) and by joint surfaces $\left(\sigma_{3}\right)$. In contrast, cleavers are rarely made completely parallel to bedding, because cleaver bits cannot be derived along parallel bedding planes. Hence the cleaver form is controlled by the physical properties of the raw material itself. Similar constraints can be seen with other raw materials in the Hunsgi and Baichbal Valleys. For example, while granite was used to manufacture handaxes, there are no cleavers made of this material, because the granite was not conducive to refined flaking or production of flat-edged bits. While physical limitations of the raw material certainly influenced biface forms and shapes, not all design criteria can be reduced to the constraints imposed by raw materials. For instance, limestone-produced handaxes could easily have been made on flakes, but they were not. Thus, raw material influence does not fully explain tool forms. Instead, certain biface attributes may have been a matter of the manufacturer's choice. Indeed, while granite and schist materials in the Hunsgi and Baichbal Valleys possess different types of fabric orientation, the forms of handaxes made from these rocks share properties with those fashioned from limestone, suggesting the desire to follow established design templates regardless of the material used. Thus, biface types and forms found at the Isampur quarry and in Acheulian assemblages throughout the valleys may reflect both intentional design considerations as well as constraints imposed by raw material.

If hominids visiting the Isampur locality employed different tool production methods to produce different tool types (i.e., handaxes, cleavers), the question is raised concerning the degree to which Middle Pleistocene hominids anticipated their tool needs. If planning is defined as a set of notions regarding the appropriate sequence of actions involved in tool production, from procurement of raw materials to the achievement of a desired end product (Belfer-Cohen and Goren-Inbar 1994; Schick 1994), then the Isampur hominids practiced some degree of forethought. On the whole, the technological evidence from Isampur indicates a systematic approach to biface manufacture, in which a number of steps were involved. The steps included coalescence at a location which yielded adequate limestone materials, procurement of certain sized slabs within the locality for production of specific tools, preparation of thick slabs for cleaver manufacture, and successful production of different types of bifacial tools. These preparatory and manufacturing stages indicate that hominids probably envisioned biface manufacture prior to the selection of natural clasts and, once clasts were struck, particular end results were desired. Thus, handaxes and cleavers were clearly distinct elements created by different reduction methods, indicating that hominids practiced some degree of predetermination in producing different artifact types.

Since methods for biface manufacture were identified at the Isampur quarry, 
we initiated a preliminary comparative analysis of limestone bifaces from other localities in the Hunsgi and Baichbal Valleys. This analysis tends to support the observations about manufacturing methods and mineralogical attributes obtained from the Isampur quarry artifacts, thereby providing some interesting inferences concerning biface discard behaviors. Our observations of the Acheulian bifaces in other localities appear to indicate that handaxes were usually made parallel to bedding and cleavers were usually made subparallel to bedding, thus conforming to the manufacturing method observed in the Isampur quarry. Moreover, relatively high proportions of the bifaces were discarded without intensive edge retouch. At Mudnur VIII, for instance, a small cluster of large limestone handaxes was reexamined. These handaxes were manufactured parallel to bedding, and their mineralogical characteristics were also preserved (joints and cleavages on tips and butts, cortical bedding on dorsal and ventral surfaces), indicating minimal retouch. This finding is consistent with an earlier hypothesis that Mudnur VIII represented a stone tool cache, indicating that once these pieces were manufactured, they were placed in a particular spot but not reused (Paddayya and Petraglia 1993). In localities where a range of activities probably occurred (e.g., Hunsgi V, Hunsgi VI, Mudnur X), observations indicate that handaxes were typically made parallel to bedding planes while cleavers were usually made oblique or subparallel to bedding, with joints, cleavages, and cortical bedding traces well preserved, again indicative of lack of substantial edge retouch (see examples in Figures 21 and 22). The Hunsgi-Baichbal evidence appears to replicate patterns found for Acheulian assemblages at Olduvai, which were considered to be minimally retouched (Jones 1994).

The finding of minimally retouched bifaces at some distance from quarries raises the question why these tools were discarded without further reduction. Several potential answers involve the nature of the limestone itself and behavioral factors. Limestone is certainly ubiquitous and abundant throughout the Hunsgi and Baichbal Valleys; this situation may have led to a higher discard level for limestone tools compared to those made of more geographically restricted raw materials. But this is not a completely satisfactory answer since surveys have shown that limestone quarries are not evenly distributed along the limestone-bearing landscape. Another raw material property that may have played a role in tool discard is that limestone bifaces may be difficult to thin, thus creating high edge angles during edge retouching.

While physical properties of the raw material itself probably played a role in biface discard before intensive retouch was applied, behavioral factors may also account for this discard phenomenon. Behavioral reasons include the possibilities that the shaped bifaces were no longer useful for their intended activities or that a little-understood ancestral pattern was being followed during the Lower Paleolithic. Along these lines, Binford $(1983,1984,1989)$ advocates a view that Middle Pleistocene hominids practiced settlement behaviors unlike those observed in the archaeological record produced by Homo sapiens, suggesting that early hominids possessed a shorter-term ability for strategic planning. Thus, while the Isampur data imply that some degree of forethought was employed 
during the stone tool manufacturing process, observations also indicate Acheulian manufacturing methods and the resultant stone tool forms underwent little change for several hundred thousand years. This evidence, taken together with the fact that the Hunsgi and Baichbal Valley localities contain minimally retouched bifaces, implies that Middle Pleistocene hominids acted in a fashion which is not currently well known or understood. The regularized stone tool manufacturing methods and the discard of minimally retouched tools appear to differ from the geographically and situationally diverse stone tool records and tactics of the Late Pleistocene. At this stage of our investigations, these very intriguing patterns and behavioral contrasts defy easy explanation; the questions they raise must remain unanswered at this time. These raw material studies and behavioral analyses may, however, be amplified with the data sets from the Hunsgi and Baichbal Valleys, as there are over one hundred known Acheulian localities throughout the basin, at various distances from the Isampur quarry, and, furthermore, future survey will certainly identify additional Acheulian quarries.

Beyond the Indian subcontinent, the Isampur study has implications for temporal and geographic discussions about the meaning of various Lower Paleolithic stone tool industries. While continued use of the term "Acheulian" implies some degree of continuity (e.g., Isaac 1986), size differences have also been pointed out within Acheulian assemblages (Crompton and Gowlett 1993), and shape differences have been noted among Acheulian assemblages situated in Africa, Europe, and the Near East (Wynn and Tierson 1990). Unfortunately, however, the degree to which there are temporal and geographic variations within the Acheulian has not been well documented. The Isampur locality, situated as it is on the Indian subcontinent, provides paleoanthropologists with a critical geographic point often ignored or underrepresented in the comparative literature. As has been pointed out for decades, but little studied, India's biface technology appears to be generally consistent with Acheulian assemblages recognized to the west, especially with respect to the manufacture of deliberately flaked tool forms (i.e., handaxes, cleavers). The Isampur quarry appears to support the claim that there were targeted designs and a shared learning tradition within the Acheulian (Schick 1994), although geographic and temporal flexibility in stone tool manufacture and hominid adaptations will likely be identified in the future.

While gross assemblage patterns may exist, the Isampur data cannot be taken as representative of the stone assemblage record of an entire subcontinent, and, indeed, it has been pointed out that Acheulian biface assemblages of India do vary as a result of differences in raw materials and manufacturing techniques (e.g., Misra 1987; Petraglia 1998). On the other hand, while there is some degree of variation within the Acheulian of India, the gross assemblage characteristics surely do contrast with the core/flake assemblages of Eastern Asia, even if Lower Paleolithic "Mode II bifaces" have been identified in China (Huang 1989; Clark 1994; Schick 1994). The East Asian biface examples do not conform to some of the deliberate shaping characteristics displayed in the Indian biface assemblages, and it has been shown that shaped bifaces could be produced 
in places where the Acheulian is not present (Schick 1994). Thus, these major geographic, temporal, and technological differences continue to require explanation, and no single explanation probably will suffice. Given the Middle Pleistocene evidence from the Hunsgi and Baichbal Valleys, however, it is safe to say that, at least here, stone tool similarities and differences are intimately tied to aspects of cognition, adaptive behaviors, and raw material conditions.

\section{NOTES}

1. Petraglia's sustained research project in India has been supported by the Office of International Relations, Smithsonian Institution; the Human Origins Program, National Museum of Natural History; the Leakey Foundation; and the Boise Foundation. Paddayya has received long-term support from Deccan College, Pune, for his surveys and excavations. Petraglia thanks Rick Potts, Alison Brooks, John Yellen, and Mike Noll for many illuminating conversations concerning Lower Paleolithic technology. Comments by Lawrence Straus, Mike Noll, and several anonymous reviewers on a draft of this article helped to clarify the presentation and terminology. Linda Sohl of Columbia University assisted LaPorta with the stereonets. Logistical support for our work in India was provided by Bilal Khrisat, S.K. Aruni, D.D. Phule, and S. Jadhav. We appreciate the cooperation of the landowners of the Isampur quarry, Aminappa Harnal and Basareddy Navadgi, for allowing us to work on their land.

2. The stereographic projection is a laboratory and field method which structural geologists employ as a handheld, manual database, used to record and illustrate petrofabric data. The organization of petrofabric data begins with orientation measurements plotted as planes within a hemisphere. A shallowly dipping plane, such as bedding $\left(\sigma_{1}\right)$, will plot close to the perimeter of the stereonet. The more inclined orientations, such as foliation $\left(\sigma_{2}\right)$, will plot as intermediate inclinations within the stereonet. The most steeply inclined fabric, such as joints, will be oriented the furthest away from the outer perimeter. The stereonet itself should be viewed as a hemisphere, and the planes of all orientation measurements will be inclined to the hemisphere at some angle. The most shallowly dipping planes will plot close to the perimeter of the hemisphere, whereas the most steeply dipping planes will plot towards the center, or bottom, of the hemisphere.

3. Inclined slabs may also result from natural karstification. The behavioral evidence here is based on the archaeological context of the inclined slabs, separation and breakdown of slabs, and direct flaking on some slabs. The slab removal and flaking process will be more thoroughly documented in future excavations.

4. While refitting was not conducted as part of the current project, the morphological and mineralogical similarity of much of the debitage from Trench 1 indicates that successful refits will be obtained in future laboratory studies. Refitting at quarry sources has been shown to be effective for inferring reduction methods, stone tool manufacturing sequences, and space use (Austin 1994; Petraglia 1994).

5 . As of this writing, a survey has identified another Acheulian quarry $2 \mathrm{~km}$ from Isampur.

\section{REFERENCES CITED}

Andrefsky, W., Jr., 1994, Raw-Material Availability and the Organization of Technology. American Antiquity 59:21-34. 
Austin, L., 1994, The Life and Death of a Boxgrove Biface. Pp. 119-26 in Stories in Stone (ed. by N. Ashton and A. David). Lithic Studies Society, Occasional Papers 40. London.

Barton, C.M., 1990, Beyond Style and Function: A View from the Middle Paleolithic. American Anthropologist 92:57-72.

Barton, C.M., 1997, Stone Tools, Style, and Social Identity: An Evolutionary Perspective on the Archaeological Record. Archeological Papers of the American Anthropological Association 7:141-56.

Bar-Yosef, O., 1994, The Lower Paleolithic of the Near East. Journal of World Prehistory $8: 211-65$.

Belfer-Cohen, A., and N. Goren-Inbar, 1994, Cognition and Communication in the Levantine Lower Paleolithic. World Archaeology 26:144-57.

Binford, L.R., 1983, In Pursuit of the Past. New York: Thames and Hudson.

Binford, L.R., 1984, Faunal Remains from Klasies River Mouth. New York: Academic Press.

Binford, L.R., 1989, Translating the Transition to Cultural Adaptations: An Organizational Approach. Pp. 18-41 in The Emergence of Modern Humans (ed. by E. Trinkaus). Cambridge, Eng.: Cambridge University Press.

Bordes, F., 1961, Typologie du Paléolithique Ancien et Moyen. Paris: Centre National de la Recherche Scientifique.

Callahan, E., 1979, The Basics of Biface Knapping in the Eastern Fluted Point Tradition. Archaeology of Eastern North America 7:1-180.

Clark, J.D., 1994, The Acheulian Industrial Complex in Africa and Elsewhere. Pp. 451-69 in Integrative Paths to the Present: Paleoanthropological Advances in Honor of F. Clark Howell (ed. by R.S. Corruccini and R.L. Ciochon). Englewood Cliffs, N.J.: Prentice-Hall.

Crompton, R.H., and J.A.J. Gowlett, 1993, Allometry and Multidimensional Form in Acheulean Bifaces from Kilombe, Kenya. Journal of Human Evolution 25:175-99.

Davidson, I., and W. Noble, 1993, Tools and Language in Human Evolution. Pp. 36888 in Tools, Language and Cognition in Human Evolution (ed. by K.R. Gibson and T. Ingold). Cambridge, Eng.: Cambridge University Press.

Dibble, H.L., 1987, The Interpretation of Middle Paleolithic Scraper Morphology. American Antiquity 52:109-17.

Dibble, H.L., 1995, Middle Paleolithic Scraper Reduction: Background, Clarification, and Review of the Evidence to Date. Journal of Archaeological Method and Theory 2:299 368.

Ericson, J.E., and B.A. Purdy, eds., 1984, Prehistoric Quarries and Lithic Production. Cambridge, Eng.: Cambridge University Press.

Goring-Morris, A.N., 1996, Square Pegs into Round Holes: A Critique of Neeley and Barton. Antiquity 70:130-35.

Gowlett, J.A.J., 1984, Mental Abilities of Early Man: A Look at Some Hard Evidence. Pp. 167-92 in Hominid Evolution and Community Ecology (ed. by R. Foley). New York: Academic Press.

Gowlett, J.A.J., and R.H. Crompton, 1994, Kariandusi: Acheulean Morphology and the Question of Allometry. African Archaeological Review 12:1-40.

Huang, W., 1989, Bifaces in China. Human Evolution 4:87-92.

Isaac, G.L., 1986, Foundation Stones: Early Artefacts as Indicators of Activities and Abilities. Pp. 221-41 in Stone Age Prehistory (ed. by G.N. Bailey and P. Callow). Cambridge, Eng.: Cambridge University Press. 
Jhaldiyal, R., 1997, Formation Processes of the Prehistoric Sites in the Hunsgi and Baichbal Basins, Gulbarga District, Karnataka. Ph.D. diss., University of Pune, India.

Jones, P., 1979, Effects of Raw Material on Biface Manufacture. Science 204:835-36. Jones, P., 1994, Results of Experimental Work in Relation to the Stone Industries of Olduvai Gorge. Pp. 254-98 in Olduvai Gorge, vol. 5 (ed. by M.D. Leakey and D.A. Roe). Cambridge, Eng.: Cambridge University Press.

Kaufman, D., 1995, Microburins and Microliths of the Levantine Epipaleolithic: A Comment on the Paper by Neeley and Barton. Antiquity 69:375-81.

Kuhn, S.L., 1992, Blank Form and Reduction as Determinants of Mousterian Scraper Morphology. American Antiquity 57:115-28.

LaPorta, P.C., 1997, The Prehistoric Mining Technology of the Cambro-Ordovician Carbonates of the Walkill River Valley of Northwestern New Jersey. Geological Society of America Abstracts with Programs 29(6):A-146.

LaPorta, P.C., 1999, The Stratigraphy and Structure of the Cambrian and Ordovician Carbonates of the Walkill River Valley: The Nature of the Diagenesis of Chert and Its Archaeological Potential. Ph.D. diss., City University of New York, New York.

Leakey, M.D., 1971, Olduvai Gorge, vol. 3. Cambridge, Eng.: Cambridge University Press.

Leng, J., 1992, Early Paleolithic Technology in China and India. Ph.D. diss., Washington University, St. Louis.

McPherron, S., 1994, A Reduction Model for Acheulian Biface Morphology. Ph.D. diss., University of Pennsylvania, Philadelphia.

Mellars, P., 1996, The Neanderthal Legacy. Princeton, N.J.: Princeton University Press.

Misra, V.N., 1987, Middle Pleistocene Adaptations in India. Pp. 99-119 in The Pleistocene Old World (ed. by O. Soffer). New York: Plenum Press.

Neeley, M.P., and C.M. Barton, 1994, A New Approach to Interpreting Late Pleistocene Microlith Industries in Southwest Asia. Antiquity 68:275-88.

Noll, M.P., and S.H. Ambrose, 1998, The Implications of Large Cutting Tools at Isimila Korongo Prehistoric Site, Tanzania, for Acheulean Typology. Unpub. MS in possession of the authors.

Paddayya, K., 1982, The Acheulian Culture of the Hunsgi Valley (Peninsular India): A Settlement System Perspective. Poona, India: Deccan College.

Paddayya, K., 1989, The Acheulian Culture Localities along the Fatehpur Nullah, Baichbal Valley, Karnataka (Peninsular India). Pp. 21-28 in Old Problems and New Perspectives in the Archaeology of South Asia (ed. by J.M. Kenoyer). Madison: University of Wisconsin Press.

Paddayya, K., and M.D. Petraglia, 1993, Formation Processes of Acheulean Localities in the Hunsgi and Baichbal Valleys, Peninsular India. Pp. 61-82 in Formation Processes in Archaeological Context (ed. by P. Goldberg, D.T. Nash, and M.D. Petraglia). Madison, Wisc.: Prehistory Press.

Paddayya, K., and M.D. Petraglia, 1995, Natural and Cultural Formation Processes of the Acheulian Sites of the Hunsgi and Baichbal Valleys, Karnataka. Pp. 333-51 in Quaternary Environments and Geoarchaeology of India (ed. by S. Wadia, R. Korisettar, and V.S. Kale). Memoir 32. Bangalore: Geological Society of India.

Paddayya, K., and M.D. Petraglia, 1997a, Acheulian Workshop at Isampur, Hunsgi Valley, Karnataka: A Preliminary Report. Bulletin of the Deccan College Post-Graduate and Research Institute 56-57:3-26.

Paddayya, K., and M.D. Petraglia, 1997b, Isampur: An Acheulian Workshop Site in 
the Hunsgi Valley, Gulbarga District, Karnataka. Man and Environment 22(2):95-100.

Petraglia, M.D., 1994, Reassembling the Quarry: Quartzite Procurement and Reduction along the Potomac. North American Archaeologist 15:283-319.

Petraglia, M.D., 1998, The Lower Paleolithic of India and Its Bearing on the Asian Record. Pp. 343-90 in Early Human Behaviour in Global Context (ed. by M. Petraglia and R. Korisettar). London: Routledge Press.

Petraglia, M.D., and R. Potts, 1994, Water Flow and the Formation of Early Pleistocene Artifact Sites in Olduvai Gorge, Tanzania. Journal of Anthropological Archaeology 13:228-54.

Potts, R., and M. Noll, 1998, The Oldest Excavated Quarry Site: Olorgesailie, Kenya. Paper presented at the Society for American Archaeology Meetings, Seattle, Washington.

Radhakrishna, B.P., and R. Vaidyanathan, 1994, Geology of Karnataka. Bangalore: Geological Survey of India.

Roe, D.A., 1964, The British Lower and Middle Palaeolithic: Some Problems, Methods of Study and Preliminary Results. Proceedings of the Prehistoric Society 30:24567.

Roe, D.A., 1968, British Lower and Middle Palaeolithic Handaxe Groups. Proceedings of the Prehistoric Society 34:1-82.

Rolland, N., and H.L. Dibble, 1990, A New Synthesis of Middle Paleolithic Variability. American Antiquity 55:480-99.

Schick, K.D., 1986, Stone Age Sites in the Making: Experiments in the Formation and Transformation of Archaeological Occurrences. BAR International Series 319. Oxford.

Schick, K.D., 1994, The Movius Line Reconsidered: Perspectives on the Earlier Paleolithic of Eastern Asia. Pp. 569-96 in Integrative Paths to the Present: Paleoanthropological Advances in Honor of F. Clark Howell (ed. by R.S. Corruccini and R.L. Ciochon). Englewood Cliffs, N.J.: Prentice-Hall.

Szabo, B.J., C. McKinney, T.S. Dalbey, and K. Paddayya, 1990, On the Age of the Acheulian Culture of the Hunsgi-Baichbal Valleys, Peninsular India. Bulletin of the Deccan College Post-Graduate and Research Institute 50:317-21.

White, M., 1995, Raw Materials and Biface Variability in Southern Britain: A Preliminary Examination. Lithics 15:1-20.

Wynn, T., 1979, The Intelligence of Later Acheulean Hominids. Man 14:371-91.

Wynn, T., 1989, The Evolution of Spatial Competence. Urbana and Chicago: University of Illinois Press.

Wynn, T., and F. Tierson, 1990, Regional Comparisons of the Shapes of Later Acheulean Handaxes. American Anthropologist 92:73-84. 